\title{
Design and Syntheses of Some New 5-[Benzenesulphonamido]- 1,3,4-thiadiazol-2-sulphonamide as Potent Antiepileptic Agent
}

\author{
Mahavir R. Chhajed, ${ }^{a}{ }^{@}$ Anil K. Shrivastava, ${ }^{\mathrm{b}}$ and Vijay S. Taile ${ }^{\mathrm{c}}$ \\ ${ }^{a}$ Department of Pharmaceutical Chemistry, Suresh Gyan Vihar University, Jaipur, India \\ ${ }^{\mathrm{b}}$ Department of Pharmaceutical Sciences, NIMS University, Jaipur, India \\ ${ }^{\mathrm{C}}$ Department of Chemistry, RTM Nagpur University, Nagpur, India \\ @Corresponding author E-mail: mahavirchhajed@rediffmail.com
}

\begin{abstract}
A QSAR study was performed on sulphonamide-1,3,4-thiadiazole derivatives using modified version of Allinger $M_{2}$ force field in Chem 3D Ultra structural descriptors. The relationship between antiepileptic activity and various descriptors was established by stepwise multiple regression analysis. The analyses have produced well predictive and statistically significant QSAR models which were further cross validated. This study helps to design and to synthesize some expectedly potent compounds. The compounds, 5-[(4-acetamido)benzenesulphonamido]-1,3,4-thiadiazol-2-(Nbenzoyl) sulphonamide (8a), 5-[(4-amino)benzenesulphonamido]-1,3,4-thiadiazol-2-(N-benzoyl) sulphonamide (9a) and 5-(4-amino) benzenesulphonamido-1,3,4-thiadiazol-2-sulphonamide (10a) were synthesized from acetazolamide by modified Schotten-Bouman synthesis method and tested for antiepileptic activity by maximal electroshock induced seizures (MES) and subcutaneous pentylenetetrazole (scPTZ) induced seizure models in mice and have shown significant activity. These compounds were further subjected to diuretic studies, showing up to $86 \%$ reduction in diuresis compared to acetazolamide.
\end{abstract}

Keywords: QSAR, antiepileptic activity, diuretic activity, 1,3,4-thiadiazole, acetazolamide.

\section{Разработка и синтез новых 5-[бензилсульфонамидо]-1,3,4- тиадиазол-2-сульфонамидов как противоэпилептических препаратов}

\author{
М. Р. Чхаед, ${ }^{a}$ А. К. Шривастава, ${ }^{\text {b }}$ В. С. Тайле \\ a Suresh Gyan Vihar University, Джайnур, Индия \\ ' NIMS University, Джайnур, Индия \\ ${ }^{\mathrm{c}}$ RTM Nagpur University, Нагnур, Индия \\ ${ }^{\circledR}$ E-mail: mahavirchhajed@rediffmail.com
}

\begin{abstract}
QSAR исследование проводили на производньх сульфонамид-1,3,4-тиадиазола с использованием структурных дескрипторов модифицированной версии силового поля MM, Allinger в Chem $3 D$ Ultra. Bзаимосвязь противоэпилептической активности и различных дескрипторов была установлена с помощью ступенчатого множественного регрессионного анализа. Получень хорошие предсказательные и статистически значимые QSAR модели, которые в дальнейшем были перекрестно подтверждены. По результатам этого исследования были предложень и синтезированы из ацетазолоамида с использованием модифицированного метода Шоттена-Боумана потенциально перспективные соединения - 5-[(4-ацетамидо)бензолсульфонамидо]-1,3,4тиадиазол-2-(N-бензоил) сульфонамид (8a), 5-[(4-амино)бензолсульфонамидо]-1,3,4-тиадиазол-2-(N-бензоил) сульфонамид (9a) и 5-(4-амино)бензолсульфонамидо-1,3,4-тиадиазол-2-сульфонамид (10a). Полученные соединения обладают противоэпилептической активностью в опытах на мышах, а также проявляют себя как эффективное противодиуретическое средство.
\end{abstract}

Ключевые слова: QSAR модели, противоэпилептическая активность, диуретическая активность, 1,3,4тиадиазол, ацетазоламид. 


\section{Introduction}

About $0.5-1 \%$ of the world's population is affected by epilepsy, one of the most common neurological disorders, and characterized by recurrent seizure attacks. The drugs that are widely used for treating epileptic seizures have failed to adequately control seizures and have unfavourable adverse effects such as ataxia, hepatotoxicity, gingival hyperplasia and megaloblastic anaemia. The restrictive treatments of epileptic seizures in patients have led to researches to discover new agents with more effectiveness and lesser toxicity. ${ }^{[1-2]}$

Acetazolamide, a heterocyclic sulphonamide; 1,3,4thiadiazole derivative, has carbonic anhydrase inhibitor activity and clinically used as diuretic agent and also used in treatment of absence seizures. It is also useful as an adjunct in the treatment of tonic-clonic, myoclonic, and atonic seizures, particularly in women whose seizures occur or are exacerbated at specific times in the menstrual cycle. However, its usefulness is transient often because of rapid development of tolerance. ${ }^{[3]}$ The problem with acetazolamide therapy as an antiepileptic agent is that, it produce diuresis and electrolyte imbalance as an adverse effect.

At least 14 different carbonic anhydrase (CA) isoforms were isolated in higher vertebrates. Several important physiological and physico-pathological functions are played by many $\mathrm{CA}$ isozymes, which are strongly inhibited by aromatic and heterocyclic sulphonamides. hCA I and hCA II inhibitors involved in the anticonvulsant activity shown by many sulphonamide drugs with CA inhibitory properties. ${ }^{[4-7]}$

Among the few reports in the literature our attention was drawn to the earlier discovery by Robin Jr. R.O. and co-workers ${ }^{[8-9]}$ reported that, the only sulphonamides, unsubstituted on the sulphonamide nitrogen in acetazolamide are highly active as carbonic anhydrase inhibitors. The 1,3,4-thiadiazole and its derivatives possess wide variety of activities. ${ }^{[10-25]}$ Furthermore, 1,3,4-thiadiazole nucleus itself exhibit anticonvulsant activity. ${ }^{[23]}$ This increases our interest to design compounds from QSAR study and synthesize the compounds accordingly, having better therapeutic index for epilepsy treatment and very low diuretic activity.

In hope of getting anticonvulsant response of 1,3,4thiadiazole nucleus itself, substitution of sulphonamide nitrogen at second position and chemically modifying fifth position acetyl group in to aromatic substituted sulphonamide group, that modification of sulphonamido group by some other chemical moiety or any substitution on sulphonamide nitrogen atom yielded structural analogues with loss of diuretic activity and will produce significant anticonvulsant activity.

We report herein designing, synthesis, antiepileptic activity and reduction in diuretic activity of acetazolamide derivatives; 5-[(4-acetamido)benzenesulphonamido]-1,3,4- thiadiazol-2-( $N$-benzoyl) sulphonamide (8a), 5-[(4-amino) benzenesulphonamido]-1,3,4-thiadiazol-2-( $N$-benzoyl)sulphonamide (9a) and 5-(4-amino)-benzenesulphonamido1,3,4-thiadiazol-2-sulphonamide (10a).

\section{QSAR Study}

Several 1,3,4-thiadiazole and sulphonamide derivatives were selected ${ }^{[26]}$ for the study (Figure 1 and Table 1) with the hope to obtain better antiepileptic agents with low dieresis. All physicochemical parameters of each compound from the

Table 1. CA-IV inhibition data for sulphonamides and 1,3,4thiadiazole derivatives used in this study.

\begin{tabular}{|c|c|c|c|}
\hline Compd & $\mathrm{R}$ & ${ }^{\mathrm{a}} \mathrm{IC}_{50}(\mu \mathrm{M})$ & ${ }^{\mathrm{b}} \mathrm{pIC}_{50}$ \\
\hline (Ia) & $-\mathrm{NH}_{2}$ & 300 & -2.47712 \\
\hline (Ib) & $-\mathrm{CH}_{2} \mathrm{NH}_{2}$ & 170 & -2.23045 \\
\hline (Ic) & $-\left(\mathrm{CH}_{2}\right)_{2} \mathrm{NH}_{2}$ & 160 & -2.20412 \\
\hline (Id) & $-\mathrm{NHCOCH}_{3}$ & 246 & -2.39094 \\
\hline (Ie) & $-\mathrm{NHCOCF}_{3}$ & 133 & -2.12385 \\
\hline (If) & $-\mathrm{NHCOCH}_{2} \mathrm{CH}_{3}$ & 232 & -2.36549 \\
\hline$(\mathbf{I g})$ & $-\mathrm{NHCO}\left(\mathrm{CH}_{2}\right)_{2} \mathrm{CH}_{3}$ & 227 & -2.35603 \\
\hline (Ih) & $-\mathrm{NHCOCH}\left(\mathrm{CH}_{3}\right)_{2}$ & 258 & -2.41162 \\
\hline (Ii) & $-\mathrm{NHCO}\left(\mathrm{CH}_{2}\right)_{3} \mathrm{CH}_{3}$ & 214 & -2.33041 \\
\hline$(\mathbf{I j})$ & $-\mathrm{NHCOCH}\left(\mathrm{CH}_{3}\right)_{3}$ & 230 & -2.36173 \\
\hline (Ik) & $-\mathrm{NHCO}\left(\mathrm{CH}_{2}\right)_{4} \mathrm{CH}_{3}$ & 63 & -1.79934 \\
\hline (II) & $-\mathrm{NHCO}\left(\mathrm{CH}_{2}\right)_{7} \mathrm{CH}_{3}$ & 66 & -1.81954 \\
\hline$(\mathbf{I m})$ & $-\mathrm{NHCOC}_{6} \mathrm{H}_{5}$ & 37 & -1.5682 \\
\hline (In) & $-\mathrm{NHCONHC}_{6} \mathrm{H}_{5}$ & 240 & -2.38021 \\
\hline (Io) & $-\mathrm{CH}_{2} \mathrm{NHCONHC}_{6} \mathrm{H}_{5}$ & 105 & -2.02119 \\
\hline (Ip) & $-\left(\mathrm{CH}_{2}\right)_{2} \mathrm{NHCONHC}_{6} \mathrm{H}_{5}$ & 75 & -1.87506 \\
\hline (Iq) & $-\mathrm{NH}(\mathrm{SO})_{2} \mathrm{C}_{6} \mathrm{H}_{5}$ & 49 & -1.6902 \\
\hline (IIa) & $-\mathrm{COCH}_{3}$ & 12 & -1.07918 \\
\hline (IIb) & $-\mathrm{COCH}\left(\mathrm{CH}_{3}\right)_{3}$ & 10 & -1 \\
\hline (IIc) & $-\mathrm{COC}_{6} \mathrm{H}_{5}$ & 15 & -1.17609 \\
\hline (IId) & $-\mathrm{COC}_{6} \mathrm{~F}_{5}$ & 2 & -0.30103 \\
\hline (IIe) & $4-\mathrm{NHCOCH}_{3} \mathrm{C}_{6} \mathrm{H}_{4} \mathrm{SO}_{2}$ & 3 & -1.44716 \\
\hline (IIf) & $3-\mathrm{F}, 4-\mathrm{NHCOCH}_{3} \mathrm{C}_{6} \mathrm{H}_{4} \mathrm{SO}_{2}$ & 1 & 0 \\
\hline (IIg) & $3-\mathrm{Cl}, 4-\mathrm{NHCOCH}_{3} \mathrm{C}_{6} \mathrm{H}_{4} \mathrm{SO}_{2}$ & 1 & 0 \\
\hline (IIh) & $3-\mathrm{Br}, 4-\mathrm{NHCOCH}_{3} \mathrm{C}_{6} \mathrm{H}_{4} \mathrm{SO}_{2}$ & 2 & -0.30103 \\
\hline (IIi) & $4-\mathrm{NH}_{2} \mathrm{C}_{6} \mathrm{H}_{4} \mathrm{SO}_{2}$ & 14 & -1.14613 \\
\hline (IIIa) & $-\mathrm{COCH}_{3}$ & 1 & 0 \\
\hline (IIIb) & -CO-2-furyl & 6 & -0.77895 \\
\hline (IIIc) & $-\mathrm{COC}_{6} \mathrm{H}_{5}$ & 17 & -1.23045 \\
\hline (IIId) & $-\mathrm{COC}_{6} \mathrm{~F}_{5}$ & 1.5 & -0.17609 \\
\hline
\end{tabular}

${ }^{\mathrm{a}} \mathrm{IC} 50$ valus were determined by CA-IV enzyme inhibition. ${ }^{\mathrm{b}}$ negative logarithmic value of IC50 (in moles) [pIC50 $=-\log 10$ IC50].



(la-q)<smiles>[R]Nc1nnc(S(N)(=O)=O)s1</smiles>

(Ila-i)<smiles>[R]N=c1sc(S(N)(=O)=O)nn1C</smiles>

(IIla-d)

Figure 1. 1,3,4-Thiadiazole and sulphonamide derivatives selected for the study. 
series were calculated and subjected to stepwise, multiple and sequential regression analysis with respect to biological activity (Table2). Correlation of each parameter was generated with biological activity and is summarised in Table 3 . The number of developed models was high, so further analysis was bases on statistically significant parameters, namely correlation coefficient $(R)$, it's square $\left(R^{2}\right)$, variance ratio $(\mathrm{F})$, cross-validation method $\left(\mathrm{Q}^{2}\right)$ standard deviation based on predicted residual sum of squares $\left(\mathrm{S}_{\text {PRESS }}\right)$ and standard deviation of error of prediction $\left(\mathrm{S}_{\mathrm{DEP}}\right)$. The parameters used in the model were almost independent, which can be seen from the Pearson correlation matrix (Table 4, Figure 2).

\section{Chemistry}

5-Amino-1,3,4-thiadiazol-2-[ $N$-(substituted benzoyl)] sulphonamides (4a-d) was prepared by hydrolysis of the benzoylated acetazolamides (3a-d), which was prepared from the acetazolamide(1) by benzoylation with substituted benzoyl chlorides (2a-d). Substituted 4-acetamidobenzenesulphonyl chlorides (7a-c) were prepared according to the literature method $^{27}$ from the substituted acetanilides (6a-c) by sulphonation with chlorosulphonic acid. The crude product was used in the next step immediately. Modified SchottenBoumann synthesis method ${ }^{[26-27]}$ was used to synthesized

Table 2. Descriptors Calculated for the QSAR Study.

\begin{tabular}{|c|c|c|c|c|}
\hline Sr. No. & Descriptor & Abbreviations & Unit & Type \\
\hline 1 & Heat of formation & $\mathrm{HF}$ & $\mathrm{kcal} / \mathrm{mol}$ & Thermodynamic \\
\hline 2 & Boiling Point & $\mathrm{BP}$ & Kelvin & Thermodynamic \\
\hline 3 & Critical Pressure & $\mathrm{CP}$ & Bar & Thermodynamic \\
\hline 4 & Critical Volume & $\mathrm{CV}$ & $\mathrm{cm}^{2} / \mathrm{mol}$ & Thermodynamic \\
\hline 5 & Critical Temperature & $\mathrm{CT}$ & & Thermodynamic \\
\hline 6 & Henry's law constant & HLC & & Thermodynamic \\
\hline 7 & Ideal gas thermal capacity & IGTC & $\mathrm{J} / \mathrm{mol} \mathrm{K}$ & Thermodynamic \\
\hline 8 & $\log p$ & LP & & Thermodynamic \\
\hline 9 & Melting Point & MP & Kelvin & Thermodynamic \\
\hline 10 & Molar Refractivity & MR & $\mathrm{cm}^{3} / \mathrm{mol}$ & Thermodynamic \\
\hline 11 & Standard Gibbs free energy & GBS & $\mathrm{kJ} / \mathrm{mol}$ & Thermodynamic \\
\hline 12 & Connolly accessible area & CAA & Angstrom S2 & Steric \\
\hline 13 & Connolly molecular surface area & MS & Angstrom S2 & Steric \\
\hline 14 & Connolly solvent excluded volume & CSEV & Angstrom S2 & Steric \\
\hline 15 & Ovality & & & Steric \\
\hline 16 & Principal Moment of Inertia-X & PMI- X & & Steric \\
\hline 17 & Principal Moment of Inertia-Y & PMI- Y & & Steric \\
\hline 18 & Principal Moment of Inertia-Z & PMI- Z & & Steric \\
\hline 19 & Dipole Moment & $\mathrm{D}$ & Debye & Electronic \\
\hline 20 & Dipole Moment $-\mathrm{X}$ axis & DX & Debye & Electronic \\
\hline 21 & Dipole Moment $-\mathrm{Y}$ axis & DY & Debye & Electronic \\
\hline 22 & Dipole Moment $-\mathrm{Z}$ axis & $\mathrm{DZ}$ & Debye & Electronic \\
\hline 23 & Electronic energy & $\mathrm{EE}$ & $\mathrm{eV}$ at $0{ }^{\circ} \mathrm{C}$ & Electronic \\
\hline 24 & Total energy & $\mathrm{TE}$ & $\mathrm{eV}$ & Electronic \\
\hline 25 & HOMO energy & HOMO & $\mathrm{eV}$ & Electronic \\
\hline 26 & LUMO energy & LUMO & $\mathrm{eV}$ & Electronic \\
\hline 27 & Repulsion energy & $\mathrm{RE}$ & $\mathrm{eV}$ & Electronic \\
\hline 28 & Bending energy & $\mathrm{E}_{\mathrm{b}}$ & $\mathrm{kcal} / \mathrm{mol}$ & Thermodynamic \\
\hline 29 & Charge-charge energy & $\mathrm{Ec}$ & $\mathrm{kcal} / \mathrm{mol}$ & Thermodynamic \\
\hline 30 & Charge-dipole energy & $\mathrm{Ed}$ & $\mathrm{kcal} / \mathrm{mol}$ & Thermodynamic \\
\hline 31 & Dipole-dipole energy & DDE & $\mathrm{kcal} / \mathrm{mol}$ & Thermodynamic \\
\hline 32 & Non-1,4-Van der Waals energy & NVDWE & $\mathrm{kcal} / \mathrm{mol}$ & Thermodynamic \\
\hline 33 & Stretch energy & SE & & Thermodynamic \\
\hline 34 & Stretch bend energy & SBE & $\mathrm{kcal} / \mathrm{mol}$ & Thermodynamic \\
\hline 35 & Torsion energy & TOE & $\mathrm{kcal} / \mathrm{mol}$ & Thermodynamic \\
\hline 36 & Total energy & TE & $\mathrm{kcal} / \mathrm{mol}$ & Thermodynamic \\
\hline 37 & Van der Waals energy & VDE & $\mathrm{kcal} / \mathrm{mol}$ & Thermodynamic \\
\hline
\end{tabular}


Design and syntheses of some New Sulphonamide-1,3,4-thiadiazole Derivatives

Table 3. Descriptors, observed, calculated and predicted CA-IV inhibition activity data of compounds of training set.

\begin{tabular}{|c|c|c|c|c|c|c|}
\hline \multirow{2}{*}{ Compd } & \multicolumn{3}{|c|}{ Descriptors } & \multicolumn{3}{|c|}{ pIC } \\
\hline & HLC & LUMO & VDWE & a Obs. & ${ }^{\mathrm{b}} \mathrm{Cal}$. & LOO \\
\hline (Ia) & 2.4950 & -1.4370 & 8.2817 & 7.6353 & 7.61418 & 3.228892 \\
\hline (Ib) & 2.3305 & -0.3276 & 3.1643 & 6.6177 & 6.60267 & 2.656621 \\
\hline (Ic) & 1.7620 & -0.6241 & 4.4457 & 6.8029 & 6.80039 & 2.734382 \\
\hline (Id) & 1.7620 & -0.6029 & 6.0813 & 6.7930 & 6.79324 & 2.756201 \\
\hline (Ie) & 2.3305 & -0.8487 & 1.3968 & 6.9469 & 6.92539 & 1.930475 \\
\hline (If) & 2.3305 & -0.8488 & 1.3991 & 6.9285 & 6.92513 & 1.737577 \\
\hline (Ig) & 2.3305 & -0.8377 & 2.7005 & 6.9248 & 6.90509 & 1.952210 \\
\hline (Ih) & 2.3305 & -0.8317 & 3.7304 & 6.8950 & 6.87545 & 1.953405 \\
\hline (Ii) & 2.3305 & -0.8289 & 3.8343 & 6.9654 & 6.94487 & 1.951018 \\
\hline$(\mathbf{I j})$ & 2.3305 & -0.5802 & 6.5330 & 6.6646 & 6.66516 & 1.588046 \\
\hline (Ik) & 2.3305 & -0.5625 & 7.1177 & 6.6904 & 6.68507 & 1.610167 \\
\hline (II) & 2.3305 & -0.8294 & 5.4088 & 6.9343 & 6.94855 & 1.440459 \\
\hline (Im) & 2.3305 & -1.2295 & 8.0392 & 6.4709 & cro & cro \\
\hline (In) & 2.3305 & -0.7771 & 4.3643 & 7.0677 & 7.09076 & 1.652787 \\
\hline (Io) & 2.3305 & -1.8565 & 4.7188 & 8.0725 & 7.98791 & 1.762105 \\
\hline (Ip) & 2.3305 & -0.9266 & 3.1096 & 7.3222 & 7.27296 & 0.889326 \\
\hline$(\mathbf{I q})$ & 1.7620 & -0.9547 & 4.8646 & 7.3505 & 7.29577 & 1.256420 \\
\hline (IIa) & 1.7620 & -0.8601 & 6.5776 & 6.9636 & 6.97175 & 1.278754 \\
\hline (IIb) & 1.7620 & -0.9373 & 8.5701 & 7.0206 & 7.06207 & 2.440922 \\
\hline (IIc) & 2.3305 & -1.0746 & 8.1744 & 7.2723 & 7.27390 & 1.662270 \\
\hline (IId) & 1.7620 & -0.9003 & 10.0460 & 7.1909 & 7.21692 & 1.771029 \\
\hline (IIe) & 1.7620 & -0.8147 & 11.3092 & 7.1254 & 7.19688 & 1.963489 \\
\hline (IIf) & 2.3305 & -1.3112 & 7.8988 & 7.4437 & 7.48955 & 2.344829 \\
\hline (IIg) & 2.3305 & -2.0134 & 9.1096 & 8.1297 & 8.08186 & 2.253290 \\
\hline (IIh) & 1.7620 & -0.7769 & 10.8721 & 6.9047 & 6.91702 & 2.134695 \\
\hline (IIi) & 7.3867 & -1.4747 & 1.1745 & 8.5932 & 8.57619 & 2.476107 \\
\hline (IIIa) & 7.3196 & -1.6986 & 1.0305 & 8.8500 & 8.88264 & 2.698101 \\
\hline (IIIb) & 7.5169 & -1.6800 & 2.1094 & 8.8937 & 8.91858 & 2.698101 \\
\hline (IIIc) & 7.7864 & -1.7131 & 2.3540 & 9.1877 & 9.05720 & 2.298853 \\
\hline (IIId) & 4.8975 & -1.2736 & 3.0051 & 8.0309 & 8.09029 & 2.476107 \\
\hline
\end{tabular}

a Observed value

${ }^{\mathrm{b}}$ Calulated (Cal) and predicted (LOO) values of pIC from Model II

${ }^{\mathrm{cro}}$ Compound removed as outlier

Table 4. Pearson Correlation Matrix for descriptors influencing inhibition of CA-IV.

\begin{tabular}{ccccc}
\hline & HLC & LUMO & VDWE & $\mathrm{pIC}_{50}$ \\
\hline HLC & 1.000 & & & \\
LUMO & -0.600 & 1.000 & 1.000 & \\
VDWE & -0.560 & 0.113 & -0.130 & 1.000 \\
pIC $_{50}$ & 0.787 & -0.792 & & \\
\hline
\end{tabular}

5-[(4-acetamido) substituted benzenesulphonamido]-1,3,4thiadiazol-2-[N-(substituted benzoyl)] sulphonamides (8a-g), where the nucleophilic substitution reaction occurs. In this reaction acetone:water mixture $(1: 1)$ was used instead of pyridine, sodium hydroxide or any other strong base. Compounds (8a-g) were prepared from the 5-amino-1,3,4-
thiadiazol-2-[N-(substituted benzoyl)] sulphonamides (4a-d) (Scheme 1) and substituted benzene sulphonyl chlorides (7a-c) (Scheme 2). After purification, further, subjected to hydrolysis with aqueous sodium hydroxide (20 \%) solution to obtain the compounds (9a-g) while, 5-(4-amino) benzenesulphonamido-1,3,4-thiadiazol-2-sulphonamides 


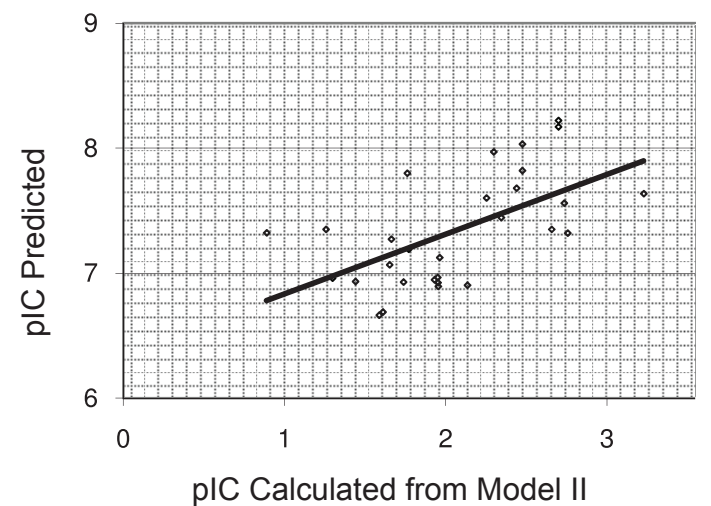

Figure 2. Predictive performance of the model II built on datasets for 29 compounds. The plots show the correlations between predicted (in cross validation) versus experimental log IC values.

(10a-b) were obtained by hydrolysis of (9a and $9 \mathrm{~g}$ ) using 70 $\%$ sulphuric acid (Scheme 3).

The FT-IR spectra show $\mathrm{S}=\mathrm{O}$ stretching at $1070-1030$, sulphonamide stretching at1177-1125 $\mathrm{cm}^{-1}$, sulphonamide $\mathrm{N}-\mathrm{H}$ stretching at $3385-3265 \mathrm{~cm}^{-1}$, C-S stretching at 712$662 \mathrm{~cm}^{-1}, \mathrm{~S}=\mathrm{O}$ stretching at $1128-1026 \mathrm{~cm}^{-1}$, but $\mathrm{C}=\mathrm{O}$ stretching peak at $1687-1513 \mathrm{~cm}^{-1}$ is absent in compounds (10a-b). The ${ }^{1} \mathrm{H}-\mathrm{NMR}$ spectra of all compounds indicated expected peaks in the region of 1.249-1.254 $\delta$ ppm singlet of $\mathrm{Ar}-\mathrm{SO}_{2} \mathrm{NH}$, while multiplets of aromatic ring are in the range of $6.6-8.2 \delta \mathrm{ppm}$. Thin layer chromatography (TLC) was run throughout the reaction to optimize the reaction for purity and completion.

\section{Pharmacology}

The synthesized derivatives obtained from the reaction sequence were administered orally into mice and evaluated for their antiepileptic activity in maximal electroshock (MES) ${ }^{[28-29]}$ and subcutaneous pentylenetetrazole (scPTZ) ${ }^{[30]}$ using a dose of $100 \mathrm{mg} / \mathrm{kg}$. The same derivatives were also studied for their diuretic activity in conscious rats, by collecting urine for four hrs. The results of antiepileptic and diuretic activity are shown in Table 5 and Table 6 respectively.

\section{Results and Discussion}

The descriptors of 1,3,4-thiadiazole were found to have good correlation with biological activity for designing antiepileptic agent which are summarised in Table 3. Herein the result of QSAR study for antiepileptic activity of the mentioned series are reported.

The Model II tested for 29 compounds as a test set. The predicted activity shows linear relationship with observed activity in the test set $(\mathrm{R}=0.9310)$ showing the robustness of the model. Henry's law constant (HLC), lowest unoccupied molecular orbital energy (LUMO) and Van der Waals energy (VDWE) have better correlation with biological activity and have low value of standard deviation. The data show (Model II) overall significant level greater than a 99.9 as it exceeded the tabulated $\mathrm{F}$ value and $\mathrm{Q}^{2}$ value found to be greater than 0.5 . The equation was validated by leave one out cross validation method and bootstrapping method as an internal validation, which gives statistically significant values.

Epileptic mediators are membrane based and increasing the lipophillic nature of antiepileptic drug molecule may improve its pharmacokinetic and pharmacodynamic properties. Increase in lipophilicity and minimum electronic interference increases antiepileptic activity suggested by positive value of HLC, VDWE and negative value of LUMO, as former two are molecular properties describing thermodynamic and later one is molecular property describing electronic parameters of the moiety. Normally both of parameters are referred to certain groups, thus substitution of bulkier, lipophillic, aromatic group will contribute to

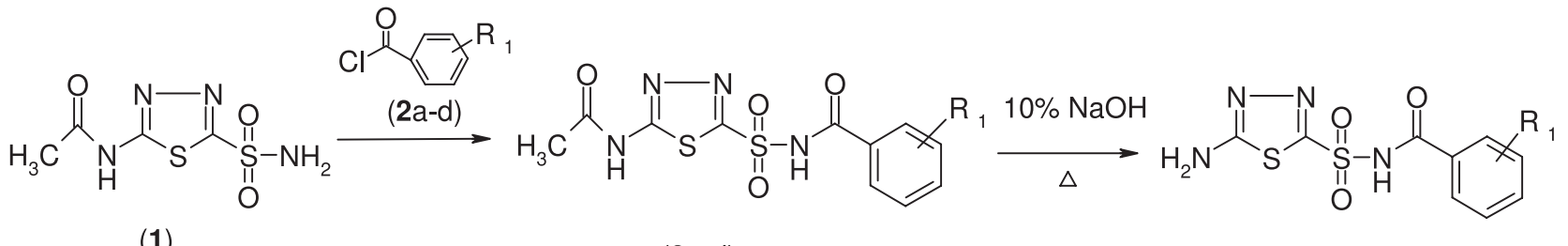

(1)

$(3 a-d)$

$(4 a-d)$

$\mathrm{R}_{1}=\mathrm{H}, p-\mathrm{Cl}, p-\mathrm{NO} 2, m-\mathrm{NO} 2$

Scheme 1.<smiles>[R]c1cccc(N)c1</smiles>

(5a-c)

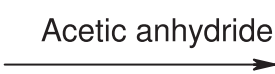

$\triangle$<smiles>[R]c1cccc(NC(C)=O)c1</smiles>

(6a-c)<smiles>[R]c1cc(NC(C)=O)ccc1S(=O)(=O)Cl</smiles>

(7a-c)

$$
\mathrm{R}_{2}=\mathrm{H} ; 2-\mathrm{CH}_{3}, 5-\mathrm{Cl} ; 2-\mathrm{NO}_{2}, 5-\mathrm{OCH}_{3}
$$


<smiles>[R]c1cc(NC(C)=O)ccc1S(=O)(=O)Cl</smiles>

$(7 a-c)$<smiles>[R]c1cccc(C(=O)NS(=O)(=O)c2nnc(N)s2)c1</smiles>

$(4 a-d)$
Acetone : water mixture $(1: 1)$<smiles>[R]c1cccc(C(=O)NS(=O)(=O)c2nnc(NS(=O)(=O)c3ccc(NC(C)=O)cc3[R2])s2)c1</smiles>

$(9 a-g)$ $(8 a-g)$ $\mathrm{O}$<smiles>[R]c1cc(N)ccc1S(=O)(=O)Nc1nnc(S(N)(=O)=O)s1</smiles>

$(10 a-b)$

\begin{tabular}{|c|c|c|c|c|c|}
\hline Compd. No. & $\mathrm{R}_{1}$ & $\mathrm{R}_{2}$ & Compd. No. & $\mathrm{R}_{1}$ & $\mathrm{R}_{2}$ \\
\hline $8 \mathbf{a}$ & $\mathrm{H}$ & $\mathrm{H}$ & $9 b$ & $4-\mathrm{Cl}$ & $\mathrm{H}$ \\
\hline $8 b$ & $4-\mathrm{Cl}$ & $\mathrm{H}$ & $9 \mathrm{c}$ & $4-\mathrm{NO}_{2}$ & $\mathrm{H}$ \\
\hline $8 c$ & $4-\mathrm{NO}_{2}$ & $\mathrm{H}$ & 9d & $3-\mathrm{NO}_{2}$ & $\mathrm{H}$ \\
\hline 8d & $3-\mathrm{NO}_{2}$ & $\mathrm{H}$ & $9 e$ & $\mathrm{H}$ & $2-\mathrm{CH}_{3}, 5-\mathrm{Cl}$ \\
\hline $8 e$ & $\mathrm{H}$ & $2-\mathrm{CH}_{3}, 5-\mathrm{Cl}$ & 9f & $4-\mathrm{Cl}$ & $2-\mathrm{CH}_{3}, 5-\mathrm{Cl}$ \\
\hline $8 f$ & $4-\mathrm{Cl}$ & $2-\mathrm{CH}_{3}, 5-\mathrm{Cl}$ & $9 g$ & $\mathrm{H}$ & $5-\mathrm{OCH}_{3}, 2-\mathrm{NO}_{2}$ \\
\hline $8 g$ & $\mathrm{H}$ & $5-\mathrm{OCH}_{3}, 2-\mathrm{NO}_{2}$ & $10 \mathrm{a}$ & -- & $\mathrm{H}$ \\
\hline 9a & $\mathrm{H}$ & $\mathrm{H}$ & $10 \mathrm{~b}$ & -- & $5-\mathrm{OCH}_{3}, 2-\mathrm{NO}_{2}$ \\
\hline
\end{tabular}

Scheme 3.

HLC and VDWE. Furthermore, reduced electron density of $-\mathrm{NH}_{2}$ (amine and sulphonamide) increases the electrostatic attraction for receptor. The LUMO descriptor indicates the strength and orientation behaviour of molecule in an electrostatic field. It is also important in determining the behaviour of the molecule in vicinity of molecule. Based on the above results, some new derivatives of 1,3,4-thiadiazole were designed and synthesized, accordingly as depicted in Scheme 1, 2 and 3.

In this series, all the analogues show more potent anticonvulsant activity while diuretic activity is absent. In the earlier reports it was highlighted that the only sulphonamides, unsubstituted on the sulphonamide nitrogen in acetazolamide ${ }^{[8-9]}$ are highly active as carbonic anhydrase inhibitors. It is also reported that presence of electron rich atom/group attached at the para position of the aryl ring showed increased potency in the MES screen. ${ }^{[31-32]}$

All the tested compounds were found to exhibit anticonvulsant activity in MES screening; however, compound $\mathbf{8 c}$ is more potent while compound $\mathbf{1 0 b}$ shows potency similar to standard drug (Phenytion). All the synthesized compounds were active in MES screen and showed recovery without any mortality. Compound $\mathbf{8 c}$ displayed activity in the MES screen with recovery of animals in $130.30 \mathrm{sec}$ while compound $\mathbf{8 g}$ showed $100 \%$ incidence of recovery from mortality in the scPTZ test since animals does not produce any clonic convulsions. This compound exhibited rapid onset of action and long duration of activity. The most active compound in the scPTZ test, a test used to identify compound that elevates seizure threshold, were 8d and 8g. Experimental results indicated that our compound exhibited better anticonvulsant activity as compared to diuretics so could be better drugs compared to acetazolamide in treatment of convulsions (Table 5). All the compounds were screened for diuretic activity. In the diuretic study, compounds showed decrease in urine output up to $80 \%$ when compared to acetazolamide as reported in Table 6. Generally compounds possessing higher log $\mathrm{p}$ value showed higher decrease in diuretic activity. Bulkier compounds are more lipophillic and can cross blood brain barrier to exert their 
Table 5. Effect of the synthesized compounds on MES induced and scPTZ induced convulsions in mice.

\begin{tabular}{|c|c|c|c|c|c|c|c|c|}
\hline \multirow[b]{2}{*}{ Treatment } & \multirow[b]{2}{*}{$\begin{array}{c}\text { Dose } \\
(\mathrm{mg} / \mathrm{kg})\end{array}$} & \multicolumn{5}{|c|}{$\begin{array}{c}\text { MES Test } \\
\text { Time Duration (in Sec) }\end{array}$} & \multicolumn{2}{|c|}{$\begin{array}{c}\text { scPTZ Test } \\
\text { Time Duration (in Sec) }\end{array}$} \\
\hline & & flexion & extension & Clonus & stupor & Recovery & $\begin{array}{l}\text { Onset of clonic } \\
\text { convulsions } \\
\text { in sec }\end{array}$ & $\begin{array}{l}\text { Incidence of } \\
\text { protection } \\
\text { against } \\
\text { mortality (\%) }\end{array}$ \\
\hline Solvent Control & & $5.87 \pm 0.56$ & $54.15 \pm 5.61$ & $15.75 \pm 1.02$ & $147.2 \pm 6.05$ & 204.4 & $142.4 \pm 12.9$ & 00 \\
\hline Phenytoin & 100 & $3.23 \pm 0.49 * * *$ & $10.20 \pm 0.67 * * *$ & $9.23 \pm 1.78^{*}$ & $60.03 \pm 3.88 * * *$ & 126.2 & A & 100 \\
\hline Acetazolamide & 100 & $4.03 \pm 0.78^{*}$ & $12.46 \pm 1.62 *$ & $11.29 \pm 1.55^{*}$ & $85.19 \pm 4.02 * * *$ & 182.67 & $487.17 \pm 29.08$ & 16.6 \\
\hline $8 \mathbf{8}$ & 100 & $3.83 \pm 0.86^{*}$ & $10.45 \pm 0.79 * * *$ & $8.83 \pm 0.51 * * *$ & $62.86 \pm 3.80 * * *$ & 143.72 & $664.4 \pm 74.1^{*}$ & 66.6 \\
\hline $8 b$ & 100 & $3.97 \pm 0.93 *$ & $10.56 \pm 1.19 *$ & $10.76 \pm 0.64 * * *$ & $58.85 \pm 3.76^{* * *}$ & 137.43 & NT & - \\
\hline $8 \mathrm{c}$ & 100 & $3.05 \pm 0.77^{*}$ & $11.35 \pm 1.54 *$ & $9.80 \pm 1.54 *$ & $63.50 \pm 5.29 * * *$ & 113.30 & $369.16 \pm 23.64$ & 16.6 \\
\hline $8 d$ & 100 & $4.15 \pm 0.96^{*}$ & $10.48 \pm 0.77 * * *$ & $11.00 \pm 1.02 *$ & $70.96 \pm 4.83 * * *$ & 130.30 & $779.9 \pm 52.7^{*}$ & 83.3 \\
\hline $8 \mathrm{e}$ & 100 & $2.92 \pm 0.67^{*}$ & $11.49 \pm 0.88^{* * *}$ & $11.11 \pm 0.81 * * *$ & $65.30 \pm 4.00 * * *$ & 129.51 & $570.16 \pm 39.64 * * *$ & 66.66 \\
\hline $8 f$ & 100 & $3.50 \pm 0.93^{*}$ & $11.04 \pm 1.01 *$ & $12.24 \pm 1.53^{*}$ & $71.71 \pm 3.66^{* * *}$ & 158.64 & $503.16 \pm 27.30^{*}$ & 50 \\
\hline $8 g$ & 100 & $2.80 \pm 0.59^{*}$ & $10.88 \pm 1.05^{*}$ & $11.22 \pm 0.71 * * *$ & $68.15 \pm 4.23 * * *$ & 132.67 & A & 100 \\
\hline $9 a$ & 100 & $4.07 \pm 0.97 *$ & $11.55 \pm 1.43^{*}$ & $11.61 \pm 1.32 *$ & $67.47 \pm 3.01 * * *$ & 172.10 & $440.16 \pm 40.97$ & 16.6 \\
\hline $9 b$ & 100 & $3.02 \pm 0.62 *$ & $10.90 \pm 1.00 *$ & $9.65 \pm 1.88^{*}$ & $62.02 \pm 6.53 * * *$ & 155.33 & NT & - \\
\hline $9 \mathrm{c}$ & 100 & $3.57 \pm 0.66^{*}$ & $11.29 \pm 0.94 * * *$ & $10.12 \pm 0.85^{* * *}$ & $64.85 \pm 3.08^{* * *}$ & 163.98 & $396.84 \pm 41.87$ & 33.33 \\
\hline 9d & 100 & $3.42 \pm 0.81 *$ & $12.47 \pm 1.61^{*}$ & $10.46 \pm 1.16^{*}$ & $59.06 \pm 4.70 * * *$ & 164.40 & NT & - \\
\hline $9 e$ & 100 & $3.52 \pm 0.64 *$ & $11.09 \pm 0.76^{* * *}$ & $9.95 \pm 1.27 *$ & $63.81 \pm 3.76^{* * *}$ & 157.67 & NT & - \\
\hline 9f & 100 & $3.62 \pm 0.86^{*}$ & $11.45 \pm 0.81 * * *$ & $11.46 \pm 1.63^{*}$ & $67.85 \pm 5.99 * * *$ & 144.71 & $780.0 \pm 12.4$ & 66.6 \\
\hline $9 g$ & 100 & $3.52 \pm 0.55^{*}$ & $12.60 \pm 1.53 *$ & $10.97 \pm 1.41 *$ & $67.82 \pm 6.46^{*}$ & 176.20 & NT & - \\
\hline $10 \mathrm{a}$ & 100 & $4.13 \pm 0.71^{*}$ & $13.13 \pm 1.12 * * *$ & $11.69 \pm 1.18^{*}$ & $66.64 \pm 4.33 * * *$ & 134.87 & $629.73 \pm 32.7$ & 66.6 \\
\hline $10 \mathrm{~b}$ & 100 & $4.07 \pm 0.79^{*}$ & $11.44 \pm 1.37 *$ & $10.39 \pm 1.22 *$ & $55.96 \pm 3.09 * * *$ & 127.29 & $667.6 \pm 95.0$ & 50 \\
\hline
\end{tabular}

Values are expressed as mean $\pm \mathrm{SEM}, \mathrm{n}=6$,

$P<0.05^{*}$ and $<0.001^{* * *}$ as compared to control group,

A: Absence of convulsions, NT: Not tested

Table 6. Diuretic activity of the synthesized compounds.

\begin{tabular}{|c|c|c|c|c|c|c|c|c|}
\hline Treatment ${ }^{\mathrm{a}}$ & $\begin{array}{l}\text { Body weight of } \\
\text { five rats }\end{array}$ & $\begin{array}{l}\text { Normal saline } \\
\text { intake }(\mathrm{mL})\end{array}$ & $\begin{array}{l}\text { Urine output } \\
(\mathrm{mL})^{\mathrm{b}}\end{array}$ & $\%$ Output & $\mathrm{T} / \mathrm{C}$ & $\mathrm{T} / \mathrm{S}$ & $\begin{array}{l}\% \text { Diuretic } \\
\text { activity }^{c}\end{array}$ & $\begin{array}{l}\% \text { Reduction in } \\
\text { Diuretic Activity }\end{array}$ \\
\hline Control & 730 & 36.5 & 7.2 & 19.73 & 1.0 & & & \\
\hline Acetazolamide & 660 & 33 & 20.7 & 62.73 & 3.18 & 1.0 & 100 & 0 \\
\hline $8 \mathbf{a}$ & 690 & 34.5 & 3.8 & 11.01 & 0.56 & 0.184 & 18.4 & 81.6 \\
\hline $8 f$ & 542 & 27.1 & 2.9 & 10.7 & 0.54 & 0.14 & 14 & 86 \\
\hline $9 e$ & 769 & 38.5 & 5.3 & 13.77 & 0.697 & 0.256 & 25.6 & 74.4 \\
\hline $9 h$ & 680 & 34 & 4.1 & 12.06 & 0.569 & 0.198 & 19.8 & 80.2 \\
\hline $10 \mathrm{a}$ & 687 & 34.4 & 12.4 & 36.047 & 1.72 & 0.599 & 59.9 & 40.1 \\
\hline
\end{tabular}

${ }^{\mathrm{a}}$ The animals of each groups received normal saline $(5 \mathrm{~mL} / 100 \mathrm{~g}$ p.o.). Except the control group, the animals of each group received the dose of $45 \mathrm{mg} / \mathrm{kg}$. $\mathrm{n}=6$,

${ }^{\mathrm{b}}$ Urine volume collected in $4 \mathrm{hr}$,

${ }^{\mathrm{c}}$ Diuretic activity $=(\mathrm{T} / \mathrm{S}) \times 100$,

${ }^{\mathrm{d}}$ Compared to standard

$\mathrm{T} / \mathrm{C}=$ ratio of test to control,

$\mathrm{T} / \mathrm{S}=$ ratio of test to standard 
effect at CNS. Present study explored that substitution of 1,3,4-thiadiazoles at third position and sulphonamido moiety at fifth position leads to the development of new chemical entities with potent anticonvulsant activity as compared to diuretic activity.

Seizures are caused by abnormal stimulation of nerves in the brain by other nerves. Generally, anticonvulsants reduce the excitability of the neurons (nerve cells) of the brain. When neuron excitability is decreased, seizures are theoretically reduced in intensity and frequency of occurrence or, in some instances, are virtually eliminated. ${ }^{[1]}$ CA isozymes, which are strongly inhibited by aromatic and heterocyclic sulphonamides. hCA I and hCA II isoenzyme inhibitors involved in the anticonvulsant activity, shown by many sulphonamide drugs with CA inhibitory properties. ${ }^{[4-7]}$

The synthesized compounds showed antiepileptic effect, may be due to their inhibitory effect on brain carbonic anhydrase; specifically inhibition of hCA I and hCA II isoenzyme, leads to an increased transneuronal chloride gradient, increased chloride current, and increased inhibition.

\section{Experimental Protocols}

\section{QSAR Study}

a) The dataset and parameters. The CA inhibition data of sulphonamides and 1,3,4-thiadiazole data have been reported in terms of inhibitory concentration of $50 \%$ of enzyme inhibition $\left(\mathrm{IC}_{50}\right.$ in micromoles). The inhibition data were converted to negative logarithmic values (concentration in moles). These values were used for subsequent QSAR analyses as response variable. The models for CA-IV inhibition were constructed based on the training set and the generated models were then validated: internally (using the leave one out technique) and externally (predicting the activities of the test set). ${ }^{[28-30,33]}$ Molecular structure were generated and optimised with CS Chem Draw Ultra 6.0 and Chem 3D Ultra (Cambridge Soft.) respectively, ${ }^{[34]}$ first by molecular mechanics (MM2) and re-optimised by MOPAC-AM1 until the root mean square (RMS) gradient value becomes smaller than $0.0001 \mathrm{kcal} / \mathrm{mol} \cdot \AA$.

b) Statistical computation. The relationship between response variable (as a dependent variable) and various physicochemical as well as structural descriptors (as independent variables), were established by step-wise linear multiple regression analysis using SYSTAT 10.2 and VALSTAT running on a Pentium 4 processor (CPU $3.0 \mathrm{GHz}$ HT). ${ }^{[35-36]}$ Significant descriptors were chosen on the basis of statistical data of analysis. ${ }^{[37-38]}$

Model I

$\mathrm{pIC}=[5.3164( \pm 0.4683)]+\mathrm{HLC}[0.3005( \pm 0.1034)]+\mathrm{LUMO}[-$ $0.7018( \pm 0.3847)]+\operatorname{VDWE}[0.0835( \pm 0.0522)]$

$N=30, R=0.9186, R^{2}=0.8439$, variance $=0.1040, S D=0.3225$, $F=46.8575, \mathrm{Q}^{2}=0.7669, \mathrm{~S}_{\mathrm{PRESS}}=0.3941, \mathrm{~S}_{\mathrm{DEP}}=0.3669$

This model has an outlier (compound Im) because their residual values exceeded twice the standard error of estimate. When this outlier was removed from the dataset, a significant Model II has been found which is able to explain 0.0829 of variance of CA-IV inhibition. This model has a high internal predictivity as shown by the good $Q^{2}$ value of 0.8066 .

Model II

$\mathrm{pIC}=[5.3104( \pm 0.4189)]+\mathrm{HLC}[0.2875( \pm 0.0930)]+\mathrm{LUMO}[-$ $0.7033( \pm 0.3441)]+\mathrm{VDWE}[0.0864( \pm 0.0467)]$

$\mathrm{N}=29, \mathrm{R}=0.9310, \mathrm{R}^{2}=0.8668$, variance $=0.0829$, $\mathrm{std}=0.2879$, $\mathrm{F}=54.219, \mathrm{Q}^{2}=0.8066, \mathrm{~S}_{\text {PRESS }}=0.3633, \mathrm{~S}_{\mathrm{DEP}}=0.3374$

The parameters used in the model were almost independent, which can be seen from the Pearson correlation matrix (Table
4, Figure 2). Two best models were selected from series, out of which Model II is selected as the best. Since, this model has better statistically significant value, minimum standard deviation, low variance, and statistically significant $F$ value.

\section{Synthetic Study}

Melting point was determined in one end open capillary tubes on a Thermonik Precision melting point apparatus (C-PMP-2, Mumbai, India) and are uncorrected. Infrared (IR) spectra were recorded for the compounds on Shimadzu FT-IR 8400s spectrophotometer in $\mathrm{KBr} .{ }^{1} \mathrm{H}$ nuclear magnetic resonance $\left({ }^{1} \mathrm{H}\right.$ NMR) spectra were recorded for the compounds on Varian EM-390 apparatus. Chemical shifts are reported in parts per million (ppm) using tetramethylsilane (TMS) as an internal standard. Elemental analysis (C, H, N and S) were undertaken with Elemental Vario EL III Carlo Erba 1106 analyzer. The purity of the compounds was confirmed by thin layer chromatography using silica gel glass plates and a solvent system of benzene: ethanol $(8: 2)$. The spots were developed in iodine chamber and visualized under ultra violet lamp. The log $\mathrm{p}$ values were determined using ChemDraw software

General procedure. 5-(4-Amino)benzenesulphonamido1,3,4-thiadiazol-2-sulphonamide was synthesized in following sequence:

5-[(4-Acetamido)benzenesulphonamido]-1,3,4thiadiazol-2-(N-benzoyl)-sulphonamide (8a). [5-Amino-1,3,4thiadiazol-2-[ $N$-benzoylsulphonamide] (4a) was suspended in a 1:1 mixture of acetone-water, and the stoichometric amount of 4-acetamidobenzenesulphonyl chloride (7a) and base was added concomitantly. The reaction mixture was magnetically stirred for several hours, the solvent was evaporated, then the $\mathrm{p} H$ was adjusted to 2 with $5 \mathrm{~N}$ hydrochloric acid and the recrystallised from aqueous ethanol.

5-[(4-Amino)benzenesulphonamido]-1,3,4-thiadiazol-2-( $N$ benzoyl)sulphonamide (9a). The synthesized compound, (8a) (2.0 $\mathrm{g}, 0.0041 \mathrm{~mol}$ ) was dissolved in $20 \%$ aqueous sodium hydroxide and refluxed for 45 minutes, allowed to cool and acidified with dilute hydrochloric acid, to precipitate out the hydrolyzed product (9a), which was separated by filtration at vacuum, and recrystallised.

5-(4-Amino)benzenesulphonamido-1,3,4-thiadiazol-2sulphonamide (10a). The compound (8a) (2.0 g, $0.0042 \mathrm{~mol})$ was refluxed with $10-15 \mathrm{~mL}$ of 70 per cent sulphuric acid (3:4 by volume) for 30 minutes, allowed to cool, filtered off and rendered the filtrate alkaline with 10-20 per cent sodium hydroxide solution. The precipitate thus formed was filtered at vacuum and recrystallised to obtained compound (10a).

Adopting the above procedures, other compounds (8b-g), (9b-g) and (10b) were synthesized and characterized. The characterized data of these compounds are as follows:

$N$-[(5-amino-1,3,4-thiadiazol-2-yl)sulfonyl]benzamide (4a). Yield $76 \%$, m.p. $234^{\circ} \mathrm{C}, \mathrm{R}_{\mathrm{f}}$ 0.61. $\mathrm{m} / z$ (GC-MS): 268 (100\%, Base peak, $\mathrm{M}^{+}$). Found: C 38.04, $\mathrm{H} 2.82, \mathrm{~N} 19.72, \mathrm{~S} 22.57 \% . \mathrm{C}_{9} \mathrm{H}_{8} \mathrm{~N}_{4} \mathrm{O}_{3} \mathrm{~S}_{2}$ (284.31) requires C 38.02, H 2.84, N 19.71, S $22.56 \%$. FT-IR (KBr) $v_{\max } \mathrm{cm}^{-1}: 3446-3368(\mathrm{~N}-\mathrm{H}), 3193-3002(\mathrm{Ar} \mathrm{C}-\mathrm{H}), 1685(\mathrm{C}=\mathrm{O})$, 683-588 (C-S), $1072-1026(\mathrm{~S}=\mathrm{O}), 1326,1178$ (sulphonamide), 3070-3002 (heteroaromatic C-H), 1685-1629 (heteroaromatic $\mathrm{C}=\mathrm{N}) .{ }^{1} \mathrm{H}$ NMR $\left(\mathrm{DMSO}-d_{6}\right) \delta_{\mathrm{H}} \mathrm{ppm}: 3.320(\mathrm{~s}, 1 \mathrm{H}, \mathrm{CONH}), 7.018-$ $7.853(\mathrm{~m}, 5 \mathrm{H}, \mathrm{Ar}-\mathrm{H}), 8.025$ (s, $1 \mathrm{H}$, thiadiazole, $\mathrm{C}-\mathrm{H}), 8.611$ (s, $1 \mathrm{H}$, acetamido-H).

$N-\{[5-(\{[4-($ acetylamino $)$ phenyl $]$ sulfonyl $\}$ amino $)-1,3,4-$ thiadiazol-2-yl]sulfonylybenzamide (8a). Yield $32.54 \%$, m.p. $216^{\circ} \mathrm{C}, \mathrm{R}_{\mathrm{f}} 0.54, \log \mathrm{P} 2.159$. Found: C 42.44, H 3.12, N 14.55, S $19.87 \% . \mathrm{C}_{17} \mathrm{H}_{15} \mathrm{~N}_{5} \mathrm{O}_{6} \mathrm{~S}_{3}$ (481.52) requies $\mathrm{C} 42.40, \mathrm{H} 3.14, \mathrm{~N} 14.54$, S $19.98 \%$. m/z (GC-MS): $458\left(100 \%\right.$, Base peak, $\left.\mathrm{M}^{+}\right)$. FT-IR $(\mathrm{KBr}) v_{\max } \mathrm{cm}^{-1}: 3520-3400(\mathrm{~N}-\mathrm{H}), 3110-3012(\mathrm{Ar} \mathrm{C}-\mathrm{H}), 1700-$ 1680 (amide $\mathrm{C}=\mathrm{O}), 700-600(\mathrm{C}-\mathrm{S}), 1070-1030(\mathrm{~S}=\mathrm{O}), 1370-1335$, 1170-1155 (sulphonamide), 3265 (sulphonamide N-H), 3077-3003 
(heteroaromatic $\mathrm{C}-\mathrm{H}$ ), 3500-3220 (heteroaromatic N-H), 1640 (heteroaromatic $\mathrm{C}=\mathrm{N}) \cdot \lambda_{\max }$ (chloroform) $(\lg \varepsilon) / \mathrm{nm} \mathrm{235.}{ }^{1} \mathrm{H}$ NMR $\left(\mathrm{DMSO}-d_{6}\right) \delta_{\mathrm{H}} \mathrm{ppm}: 1.103\left(\mathrm{~s}, 1 \mathrm{H}, \mathrm{Ar}_{-} \mathrm{SO}_{2} \mathrm{H}\right), 2.378\left(\mathrm{~s}, 3 \mathrm{H}, \mathrm{CH}_{3}\right)$, $3.320(\mathrm{~s}, 1 \mathrm{H}, \mathrm{CONH}), 4.740(\mathrm{~s}, 1 \mathrm{H}, \mathrm{N}-\mathrm{H}), 7.281-7.785(\mathrm{~m}, 6 \mathrm{H}$, Ar-H), 8.025 (s, 1H, thiadiazole, C-H), 8.611 (s, 1H, acetamido-H). ${ }^{13} \mathrm{C}$ NMR $\delta$ ppm: $169.7,168.9,141.6,135.5,134.3,128.9,128.7$, $128.7,127.5,127.5,127.4,122.0,121.9,121.8,23.1$

$N-\{[5-(\{[4-($ acetylamino $)$ phenyl] sulfonyl $\}$ amino $)-1,3,4-$ thiadiazol-2-yl] sulfonyl $\}$-4-chlorobenzamide (8b). Yield $40.12 \%$, m.p. $224^{\circ} \mathrm{C}, \mathrm{R}_{\mathrm{f}} 0.62, \log \mathrm{P} 2.717$. Found: C 39.56, H 2.74, N 13.57, $\mathrm{S} 18.63 \% . \mathrm{C}_{17} \mathrm{H}_{14} \mathrm{~N}_{5} \mathrm{O}_{6} \mathrm{~S}$ Cl (515.97) requires $\mathrm{C} 39.57, \mathrm{H} 2.73, \mathrm{~N}$ 13.57, S $18.64 \%$. m/z (GC-MS): $462\left(100 \%\right.$, Base peak, M $\left.{ }^{+}\right)$. FTIR (KBr) $v_{\max } \mathrm{cm}^{-1}: 3567-3385(\mathrm{~N}-\mathrm{H}), 3108-3045(\mathrm{Ar} \mathrm{C}-\mathrm{H}), 1661-$ 1525 (amide $\mathrm{C}=\mathrm{O}), 760-636(\mathrm{C}-\mathrm{S}), 1097-1026(\mathrm{~S}=\mathrm{O}), 1383$, 1330, 1177, 1141 (sulphonamide), 3385 (sulphonamide N-H), 2920 $\left(\mathrm{CH}_{3}-\mathrm{O}\right), 1531-1482\left(\mathrm{Ar} \mathrm{C}^{-N_{2}}\right), 852(\mathrm{Ar} \mathrm{C}-\mathrm{N}) 543$ (C-Cl). $\lambda_{\max }$ (chloroform) $(\lg \varepsilon) / \mathrm{nm} \mathrm{238.}{ }^{1} \mathrm{H}$ NMR (DMSO- $\left.d_{6}\right) \delta_{\mathrm{H}} \mathrm{ppm}: 1.217(\mathrm{~s}$, $\left.1 \mathrm{H}, \mathrm{Ar}_{-} \mathrm{SO}_{2} \mathrm{H}\right), 2.332$ (s, 3H, $\left.\mathrm{CH}_{3}\right), 3.496(\mathrm{~s}, 1 \mathrm{H}, \mathrm{CONH}), 4.740$ (s, 1H, N-H), 7.242- 7.453 (m, 3H, Ar-H), 8.009 (s, 1H, thiadiazole, $\mathrm{C}-\mathrm{H}), 8.036$ (s, $1 \mathrm{H}$, Acetamido-H). ${ }^{13} \mathrm{C}$ NMR $\delta$ ppm: 170.1, 169.1, $141.0,137.3,135.4,132.2,129.5,129.1,128.8,128.7,128.2,127.6$, $122.0,121.8,22.5$

$N-\{[5-(\{[4-($ acetylamino $)$ phenyl $]$ sulfonyl\}amino $)-1,3,4-$ thiadiazol-2-yl]sulfonyl\}-4-nitrobenzamide $(\boldsymbol{8 c})$. Yield 28.13 \%, m.p. $242^{\circ} \mathrm{C}, \mathrm{R}_{\mathrm{f}} 0.58, \operatorname{LogP} 2.156$. Found: C $38.79, \mathrm{H} 2.69$, $\mathrm{N} 15.94, \mathrm{~S} 18.27 \%$. $\mathrm{C}_{18} \mathrm{H}_{17} \mathrm{~N}_{6} \mathrm{O}_{8} \mathrm{~S}_{3}(526.52)$ requires $\mathrm{C} 38.78, \mathrm{H}$ 2.68, N 15.96, S $18.27 \%$. $m / z$ (GC-MS): 531 (100\%, Base peak, $\mathrm{M}^{+}$). FT-IR (KBr) $v \quad \mathrm{~cm}^{-1}: 3367-3110(\mathrm{~N}-\mathrm{H}), 3110-3024(\mathrm{Ar}$ $\mathrm{C}-\mathrm{H}), 1445$ (amide $\mathrm{C}=\mathrm{O}$ ), 711-655 (C-S), 1128-1080 (S=O), 1348, 1313, 1184 (sulphonamide), 3238 (sulphonamide N-H), 3077-3003 (heteroaromatic C-H), 2360-2341 (heteroaromatic N-H), 1720 (heteroaromatic $\mathrm{C}=\mathrm{N}), 1515-1452\left(\mathrm{Ar} \mathrm{C}-\mathrm{NO}_{2}\right), 896-852(\mathrm{Ar} \mathrm{C}-\mathrm{N})$. $\lambda_{\max }$ (chloroform) $(\lg \varepsilon) / \mathrm{nm} 248 .{ }^{1} \mathrm{H}$ NMR (DMSO- $\left.d_{6}\right) \delta_{\mathrm{H}} \mathrm{ppm}$ : $2.232\left(\mathrm{~s}, 3 \mathrm{H}, \mathrm{CH}_{3}\right), 3.541$ (s, $\left.1 \mathrm{H}, \mathrm{CON}(-\mathrm{H}) \mathrm{Ar}\right), 7.241-7.483(\mathrm{~m}$, 4H, Ar-H), 8.017-8.259 (m, 4H, Ar-H), 8.110 (s, 1H, acetamido $\mathrm{N}-\mathrm{H}), 8.129$ (s, 1H, Sulphonamido N-H). ${ }^{13} \mathrm{C}$ NMR $\delta_{\mathrm{c}}$ ppm: 170.1 , $168.9,141.7,140.3,135.2,128.7,128.5,127.4,121.8,121.7,127.5$, 121.3, 23.0.

$N-\{[5-(\{[4-($ acetylamino $)$ phenyl $]$ sulfonyl\}amino $)-1,3,4$ thiadiazol-2-yl]sulfonyl\}-3-nitrobenzamide (8d). Yield 21.87 \%, m.p. $237^{\circ} \mathrm{C}, \mathrm{R}_{\mathrm{f}} 0.61, \log \mathrm{P} 1.481$. Found: C 38.76, H 2.69, $\mathrm{N} 15.96, \mathrm{~S} 18.29 \% . \mathrm{C}_{18} \mathrm{H}_{17} \mathrm{~N}_{6} \mathrm{O}_{8} \mathrm{~S}_{3}(526.52)$ requires $\mathrm{C} 38.78, \mathrm{H}$ 2.68, N 15.96, S $18.27 \%$. m/z (GC-MS): 534 (100\%, Base peak, $\left.\mathrm{M}^{+}\right)$. FT-IR $(\mathrm{KBr}) v \quad \mathrm{~cm}^{-1}: 3527-3415(\mathrm{~N}-\mathrm{H}), 3100-3000(\mathrm{Ar}$ C-H), 1531 (amide $\mathrm{C}=\mathrm{O}), 713-619$ (C-S), 1087 (S=O), 1352, 1311, 1176 (sulphonamide), 3265 (sulphonamide N-H), 3077-3003 (heteroaromatic C-H), 2341-2331 (heteroaromatic N-H), 1720 (heteroaromatic $\mathrm{C}=\mathrm{N}), 1456-1531\left(\mathrm{Ar} \mathrm{C}-\mathrm{NO}_{2}\right), 827(\mathrm{Ar} \mathrm{C}-\mathrm{N}) . \lambda_{\max }$ (chloroform) (lge)/nm 252. ' $\mathrm{H}$ NMR (DMSO- $\left.d_{6}\right) \delta_{\mathrm{H}}$ ppm: 2.214 (s, $\left.3 \mathrm{H}, \mathrm{CH}_{3}\right), 3.452$ (s, $\left.1 \mathrm{H}, \mathrm{CON}(-\mathrm{H}) \mathrm{Ar}\right), 7.447-7.881$ (m, 2H, Ar-H), 8.219 (s, $1 \mathrm{H}$, acetamido N-H), 8.437 (s, 1H, Sulphonamido N-H), 7.904-8.724 (m, 4H, Ar-H). ${ }^{13} \mathrm{C}$ NMR $\delta_{\mathrm{c}} \mathrm{ppm}: 169.9,169.1,148.3$, $141.3,135.3,135.1,133.2,129.6,127.4,127.2,124.5,122.4,121.4$, $121.4,22.8$.

$N-\{[5-(\{[4-($ acetylamino)-5-chloro-2-methylphenyl] sulfonyl $\}$ amino)-1,3,4-thiadiazol-2-yl] sulfonyl\} benzamide (8e). Yield $26.60 \%$, m.p. $249^{\circ} \mathrm{C}, \mathrm{R}_{\mathrm{f}}$ 0.64, $\log \mathrm{P} 3.204$. Found: C 40.79, H 3.05, $\mathrm{N} 13.20, \mathrm{~S} 18.17 \% . \mathrm{C}_{18} \mathrm{H}_{16} \mathrm{~N}_{5} \mathrm{O}_{6} \mathrm{~S}_{3} \mathrm{Cl}(529.99)$ requires $\mathrm{C} 40.79, \mathrm{H}$ 3.04, N 13.21, S 18.15\%. m/z (GC-MS): 519 (100\%, Base peak, $\left.\mathrm{M}^{+}\right)$. FT-IR (KBr) $v_{\max } \mathrm{cm}^{-1}$ : 3398-3137-(N-H), 3107-3010-(Ar $\mathrm{C}-\mathrm{H}), 1708-1685$ (amide $\mathrm{C}=\mathrm{O}), 692-621(\mathrm{C}-\mathrm{S}), 1081-1054(\mathrm{~S}=\mathrm{O})$, 1365, 1311, 1187 (sulphonamide), 3319 (sulphonamide N-H), 23602341 (heteroaromatic N-H), 1708 (heteroaromatic $\mathrm{C}=\mathrm{N}$ ), 592-532 (C-Cl), 972-846 (C-N), 2894 (C-H). $\lambda_{\max }$ (chloroform) $(\lg \varepsilon) / \mathrm{nm}$ 252. ${ }^{1} \mathrm{H}$ NMR (DMSO- $\left.d_{6}\right) \delta_{\mathrm{H}}$ ppm: $2.054\left(\mathrm{~s}, 1 \mathrm{H}, \mathrm{C}(=\mathrm{O}) \mathrm{CH}_{3}\right), 2.452$ (s, $\left.1 \mathrm{H}, \mathrm{Ar} \mathrm{C}-\mathrm{CH}_{3}\right), 3.365$ (s, $\left.1 \mathrm{H}, \mathrm{CON}(-\mathrm{H}) \mathrm{Ar}\right), 7.404-7.753(\mathrm{~m}, 3 \mathrm{H}$, Ar-H), 7.647- 7.818 (m, 2H, Ar-H), 8.124 (s, 1H, acetamido N-H), 8.548 (s, $1 \mathrm{H}$, Sulphonamido N-H). ${ }^{13} \mathrm{C}$ NMR $\delta_{\mathrm{c}} \mathrm{ppm}: 170.1,168.8$,
$140.3,136.2,134.2,134.2,132.4,128.9,128.8,127.7,127.6,127.3$, $126.3,123.0,22.6,16.2$.

$N-\{[5-(\{[4-($ acetylamino)-5-chloro-2-methylphenyl] sulfonyl $\}$ amino)-1,3,4-thiadiazol-2-yl] sulfonyl\}-4-chlorobenzamide (8f). Yield $39.44 \%$, m.p. $257^{\circ} \mathrm{C}, \mathrm{R}_{\mathrm{f}} 0.61, \operatorname{LogP} 3.763$. Found: C 38.29, $\mathrm{H} 2.65, \mathrm{~N} 12.42, \mathrm{~S} 17.07 \%$. $\mathrm{C}_{18} \mathrm{H}_{15} \mathrm{~N}_{5} \mathrm{O}_{6} \mathrm{~S}_{3} \mathrm{Cl}_{2}(564.44)$ requires $\mathrm{C}$ 38.30, H 2.68, N 12.41, S $17.04 \% . m / z$ (GC-MS): 581 (100\%, Base peak, $\mathrm{M}^{+}$). FT-IR $(\mathrm{KBr}) v_{\max } \mathrm{cm}^{-1}: 3359-3338(\mathrm{~N}-\mathrm{H}), 3082-3045(\mathrm{Ar}$ C-H), 1691-1629 (amide $\mathrm{C}=\mathrm{O}), 678-669(\mathrm{C}-\mathrm{S}), 1035(\mathrm{~S}=\mathrm{O}), 1342$, 1319, 1157 (sulphonamide), 3338 (sulphonamide N-H), 23812341 (heteroaromatic N-H), 1785-1735 (heteroaromatic $\mathrm{C}=\mathrm{N}$ ), 559 (C-Cl), 960-827 (C-N), 2943 (C-H). $\lambda_{\max }$ (chloroform) (lge) $/ \mathrm{nm}$ 248. ${ }^{1} \mathrm{H}$ NMR (DMSO- $\left.d_{6}\right) \delta_{\mathrm{H}} \mathrm{ppm}: 2.062\left(\mathrm{~s}, 1 \mathrm{H}, \mathrm{C}(=\mathrm{O}) \mathrm{CH}_{3}\right), 2.564$ (s, 1H, Ar C-CH $), 3.447$ (s, 1H, CON(-H) Ar), 7.173-7.392 (m, 2H, Ar-H), 7.423- 7.588 (m, 2H, Ar-H), 7.973 (s, 1H, acetamido N-H), 8.213 (s, $1 \mathrm{H}$, Sulphonamido N-H). ${ }^{13} \mathrm{C}$ NMR $\delta_{\mathrm{c}}$ ppm: 169.8, 169.0, 140.2, 137.4, 135.9, 135.1, 132.4, 129.1, 129.1, 128.9, 128.8, 127.7, $126.4,122.9,23.0,16.5$.

$N-\{[5-(\{[4-$ (acetylamino)-5-methoxy-2-nitrophenyl] sulfonyl\} amino)-1,3,4-thiadiazol-2-yl]sulfonyl benzamide (8g). Yield 25.30 \%, m.p. $264^{\circ} \mathrm{C}, \mathrm{R}_{\mathrm{f}} 0.52 \operatorname{LogP} 0.694$.. Found: C 38.88, H 2.88, N $15.12, \mathrm{~S}, 17.27 \% . \mathrm{C}_{18} \mathrm{H}_{15} \mathrm{~N}_{6} \mathrm{O}_{9} \mathrm{~S}_{3}(590.99)$ requires $\mathrm{C} 38.85, \mathrm{H} 2.90$, $\mathrm{N} 15.10, \mathrm{~S} 17.28 \%$. $\mathrm{m} / z$ (GC-MS): $541\left(100 \%\right.$, Base peak, $\left.\mathrm{M}^{+}\right)$. FT-IR (KBr) $v_{\max } \mathrm{cm}^{-1}: 3537-3427(\mathrm{~N}-\mathrm{H}), 3124-3028(\mathrm{Ar} \mathrm{C}-\mathrm{H})$, 1691-1528 (amide $\mathrm{C}=\mathrm{O}), 717-609(\mathrm{C}-\mathrm{S}), 1022-1078(\mathrm{~S}=\mathrm{O}), 1367$, 1333, 1181, 1157 (sulphonamide), 3265 (sulphonamide N-H), 2847 ( $\left.\mathrm{CH}_{3}-\mathrm{O}\right), 1528-1487$ ( $\mathrm{Ar} \mathrm{C}-\mathrm{NO}_{2}$ ), 823 (Ar C-N stretching). $\lambda$ (chloroform) $(\lg \varepsilon) / \mathrm{nm} \mathrm{261.}{ }^{1} \mathrm{H}$ NMR (DMSO- $\left.d_{6}\right) \delta_{\mathrm{H}} \mathrm{ppm:} 2.054$ $\left(\mathrm{s}, 1 \mathrm{H}, \mathrm{C}(=\mathrm{O}) \mathrm{CH}_{3}\right), 3.714$ (s, 1H, CON(-H) Ar), 4.245 (s, 1H, Ar $\left.\mathrm{O}-\mathrm{CH}_{3}\right), 7.204-7.938$ (m, 3H, Ar-H), 8.12- 8.417 (m, $\left.2 \mathrm{H}, \mathrm{Ar}-\mathrm{H}\right)$, 8. 241 (s, 1H, acetamido N-H), 8.548 (s, 1H, Sulphonamido N-H). ${ }^{13} \mathrm{C}$ NMR $\delta_{\text {c }}$ ppm: $169.7,169.1,159.3,138.2,137.7,134.5,132.3$, 131.1, 131.1, 130.8, 129.1, 128.9, 127.7, 127.6, 116.9, 116.5, 112.4, $55.9,22.8$.

$N$-[(5-\{[(4-aminophenyl)sulfonyl]amino $\}$-1,3,4-thiadiazol2-yl) sulfonyl]benzamide (9a). Yield $60.27 \%$, m.p. $259^{\circ} \mathrm{C}, \mathrm{R}_{\mathrm{f}}$ 0.57, LogP 2.448. Found: C 40.98, H 2.97, N 15.95, S $21.89 \%$. $\mathrm{C}_{15} \mathrm{H}_{13} \mathrm{~N}_{5} \mathrm{O}_{5} \mathrm{~S}_{3}(439.49)$ requires $\mathrm{C} 40.99, \mathrm{H} 2.98, \mathrm{~N} 15.94, \mathrm{~S} 21.89 \%$. $\mathrm{m} / \mathrm{z}$ (GC-MS): $429\left(100 \%\right.$, Base peak, $\left.\mathrm{M}^{+}\right)$. FT-IR $(\mathrm{KBr}) v_{\max } \mathrm{cm}^{-1}$ : 3573-3295 (N-H), 3075 (Ar C-H), 1687-1513 (amide $\mathrm{C}=\mathrm{O}$ ), 712 $662(\mathrm{C}-\mathrm{S}), 1128-1026(\mathrm{~S}=\mathrm{O}), 1330,1177,1125$ (sulphonamide), 3385 (sulphonamide N-H). $\lambda_{\max }$ (chloroform) (lge)/nm 238. ${ }^{1} \mathrm{H}$ NMR (DMSO- $\left.d_{6}\right) \delta_{\mathrm{H}} \mathrm{ppm}: 1.249\left(\mathrm{~s}, 1 \mathrm{H}, \mathrm{Ar}-\mathrm{SO}_{2} \mathrm{NH}\right), 3.526(\mathrm{~s}, 2 \mathrm{H}$, Ar- $\mathrm{NH}_{2}$ ), 6.895-6.923 (s, 2H, Ar-unsymmetrical pattern), 7.2368.392 (m, 3H, Ar-H), 8.143 (s, 1H, Sulphonamido N-H). ${ }^{13} \mathrm{C}$ NMR $\delta_{\text {c }}$ ppm: $170.2,152.0,134.4,132.3,129.8,128.8,128.7,128.2$, $128.1,127.6,127.6,116.5,116.3$.

$\mathrm{N}$-[(5-\{[(4-aminophenyl)sulfonyl]amino $\}-1,3,4$-thiadiazol-2yl)sulfonyl]-4-chloro benzamide (9b). Yield $70.64 \%$, m.p. $267^{\circ} \mathrm{C}$, $\mathrm{R}_{\mathrm{f}}$ 0.52, $\log \mathrm{P} 3.007$. Found: C 38.01, H 2.57, N 14.75, S 20.29 $\%$. $\mathrm{C}_{15} \mathrm{H}_{12} \mathrm{~N}_{5} \mathrm{O}_{5} \mathrm{~S}_{3} \mathrm{Cl}(473.93)$ requires C 38.01, H 2.55, N 14.78, S $20.30 \% . \mathrm{m} / z$ (GC-MS): 481 (100\%, Base peak, $\left.\mathrm{M}^{+}\right)$. FT-IR (KBr) $v_{\max } \mathrm{cm}^{-1}:$ 3561-3372 (N-H), 3097-3015 (Ar C-H), 1698 (amide $\mathrm{C}=\mathrm{O}), 763-553(\mathrm{C}-\mathrm{S}), 1087-1056(\mathrm{~S}=\mathrm{O}), 1341,1330,1170,1139$ (sulphonamide), 3324-3197 (sulphonamide $\mathrm{N}-\mathrm{H}), 782$ (C-Cl). $\lambda_{\text {max }}$ (chloroform) (lge)/nm 242. ${ }^{1} \mathrm{H}$ NMR (DMSO- $d_{6}$ ) $\delta_{\mathrm{H}} \mathrm{ppm:} 1.329$ (s, $1 \mathrm{H}, \mathrm{Ar}-\mathrm{SO}_{2} \mathrm{NH}$ ), 3.225 (s, 2H, Ar- $\mathrm{NH}_{2}$ ), 6.985-7.014 (s, 2H, Arunsymmetrical pattern), 7.623-8.432 (m, 2H, Ar-H), 8. 344 (s, 1H, Sulphonamido N-H). ${ }^{13} \mathrm{C}$ NMR $\delta_{\mathrm{c}}$ ppm: $170.1,151.5,137.5,132.2$, 130.1, 129.2, 129.1, 129.0, 128.9, 128.2, 128.1, 116.3, 116.2.

$\mathrm{N}$-[(5-\{[(4-aminophenyl)sulfonyl]amino\}-1,3,4-thiadiazol-2yl)sulfonyl]-4-nitro benzamide $(9 c)$. Yield $52.06 \%$, m.p. $283^{\circ} \mathrm{C}, \mathrm{R}$ 0.44, $\log$ P 1.263. Found: C 37.20, H 2.51, N 17.34, S $19.86 \%$. $\mathrm{C}_{15} \mathrm{H}_{12} \mathrm{~N}_{6} \mathrm{O}_{7} \mathrm{~S}_{3}(484.49)$ requires C 37.19, H 2.50, N 17.35, S 19.86 \%. $\mathrm{m} / \mathrm{z}$ (GC-MS): $512\left(100 \%\right.$, Base peak, $\left.\mathrm{M}^{+}\right)$. FT-IR (KBr) $v_{\text {max }}$ $\mathrm{cm}^{-1}$ : 3407-3126 (N-H), 3107-3010 (Ar C-H), 1708-1685 (amide $\mathrm{C}=\mathrm{O}), 692-621(\mathrm{C}-\mathrm{S}), 1515-1452\left(\mathrm{Ar} \mathrm{C}-\mathrm{NO}_{2}\right), 1054-1081(\mathrm{~S}=\mathrm{O})$, 1365, 1311, 1187 (sulphonamide), 3319 (sulphonamide N-H), 
2360-2341 (heteroaromatic N-H), 1708 (heteroaromatic C=N), 972-846 (C-N), $2894(\mathrm{C}-\mathrm{H}) . \lambda_{\max }$ (chloroform) $(\lg \varepsilon) / \mathrm{nm} \mathrm{273.}{ }^{1} \mathrm{H}$ NMR (DMSO- $\left.d_{6}\right) \delta_{\mathrm{H}} \mathrm{ppm}: 2.421\left(\mathrm{~s}, 1 \mathrm{H}, \mathrm{Ar}-\mathrm{SO}_{2} \mathrm{NH}\right), 4.032(\mathrm{~s}, 2 \mathrm{H}$, Ar- $\left.\mathrm{NH}_{2}\right), 6.985-7.014$ (s, 2H, Ar-unsymmetrical pattern), 6.6347.327 (m, 2H, Ar-H), 8.611 (s, 1H, Sulphonamido N-H). ${ }^{13} \mathrm{C}$ NMR $\delta_{\mathrm{c}}$ ppm: $169.9,151.9,151.4,140.2,129.2,128.6,128.5,128.4$, $128.1,121.3,121.3,116.4,116.2$.

$N$-[(5-\{[(4-aminophenyl)sulfonyl]amino $\}-1,3,4$-thiadiazol-2yl) sulfonyl]-3-nitro benzamide (9d). Yield $46.41 \%$, m.p. $2744^{\circ} \mathrm{C}, \mathrm{R}_{\mathrm{f}}$ 0.47, $\log P$ 1.151. Found: C 37.19, H 2.51, N 17.36, S $19.87 \%$. $\mathrm{C}_{15} \mathrm{H}_{12} \mathrm{~N}_{6} \mathrm{O}_{7} \mathrm{~S}_{3}(484.49)$ requires C 37.19, H 2.50, N 17.35, S 19.86 \%. $\mathrm{m} / \mathrm{z}$ (GC-MS): $519\left(100 \%\right.$, Base peak, $\left.\mathrm{M}^{+}\right)$. FT-IR $(\mathrm{KBr}) v_{\max }$ $\mathrm{cm}^{-1}$ : 3412-3197 (N-H), 3107-2925 (Ar C-H), 1712-1654 (amide $\mathrm{C}=\mathrm{O}), 723-681(\mathrm{C}-\mathrm{S}), 1487-1411\left(\mathrm{Ar} \mathrm{C}-\mathrm{NO}_{2}\right), 1109-1020(\mathrm{~S}=\mathrm{O})$, 1368, 1333, 1173 (sulphonamide), 3320 (sulphonamide $\mathrm{N}-\mathrm{H}$ ), 2378-2331 (heteroaromatic N-H), 1712 (heteroaromatic $\mathrm{C}=\mathrm{N}$ ), $2862(\mathrm{C}-\mathrm{H}) . \lambda_{\max }$ (chloroform) (lge)/nm 265. ' $\mathrm{H}$ NMR (DMSO$\left.d_{6}\right) \delta_{\mathrm{H}}$ ppm: $1.495\left(\mathrm{~s}, 1 \mathrm{H}, \mathrm{Ar}-\mathrm{SO}_{2} \mathrm{NH}\right), 3.503\left(\mathrm{~s}, 2 \mathrm{H}, \mathrm{Ar}-\mathrm{NH}_{2}\right), 6$. 985-7.014 (s, 2H, Ar-unsymmetrical pattern), 6. 436-7. 273 (m, 2H, Ar-H), 7.932 (s, 1H, Sulphonamido N-H). ${ }^{13} \mathrm{C}$ NMR $\delta_{\mathrm{c}}$ ppm: 169.8 , 151.4, 148.3, 135.2, 133.4, 129.9, 129.6, 128.4, 128.1, 124.3, 122.3, 116.6, 116.3 .

$N$-[(5-\{[(4-amino-5-chloro-2-methylphenyl)sulfonyl]amino\}1,3,4-thiadiazol-2-yl) sulfonyl] benzamide (9e). Yield $68.62 \%$, m.p. $263^{\circ} \mathrm{C}, \mathrm{R}_{\mathrm{f}} 0.48, \log \mathrm{P} 3.494$. Found: C 39.40, H 2.88, N 14.34, $\mathrm{S} 19.70 \% . \mathrm{C}_{16} \mathrm{H}_{14} \mathrm{~N}_{5} \mathrm{O}_{5} \mathrm{~S} \mathrm{~S}_{3} \mathrm{Cl}(487.96)$ requires $\mathrm{C} 39.38, \mathrm{H} 2.89, \mathrm{~N}$ 14.35, S $19.71 \%$. m/z (GC-MS): 495 (100\%, Base peak, M ${ }^{+}$). FTIR (KBr) $v_{\max } \mathrm{cm}^{-1}: 3467-3178(\mathrm{~N}-\mathrm{H}), 3102-2936$ (Ar C-H), 1734$1686(\mathrm{C}=\mathrm{O}), 713-690(\mathrm{C}-\mathrm{S}), 559-522(\mathrm{C}-\mathrm{Cl}), 1134-1047(\mathrm{~S}=\mathrm{O})$, 1387, 1324, 1157 (Sulphonamide), 3370 (sulphonamide N-H), 2395 (heteroaromatic N-H), 1784 (heteroaromatic $\mathrm{C}=\mathrm{N}), 2912(\mathrm{C}-\mathrm{H}$ stretching). $\lambda_{\max }$ (chloroform) (lge)/nm 272. 'H NMR (DMSO- $d_{6}$ ) $\delta_{\mathrm{H}}$ ppm: 1.249 (s, $\left.1 \mathrm{H}, \mathrm{Ar}-\mathrm{SO}_{2} \mathrm{NH}\right), 3.990\left(\mathrm{~s}, 3 \mathrm{H}, \mathrm{Ar}-\mathrm{CH}_{3}\right), 3.526$ (s, 2H, Ar- $\left.\mathrm{NH}_{2}\right), 6.895-6.923$ (s, 2H, Ar-unsymmetrical pattern), 7.236-7.581 (m, 6H, Ar-H), 7.604-7.735 (s, 2H, NH $)$, 8.367-8.392 (s, $1 \mathrm{H}$, thiadiazole, $\mathrm{C}-\mathrm{H}) .{ }^{13} \mathrm{C}$ NMR $\delta_{\mathrm{c}} \mathrm{ppm}: 170.1,147.6,135.6$, 134.3, 132.2, 130.6, 128.5, 128.5, 127.8, 127.7, 127.3, 122.6, 117.9, 16.5 .

$N$-[(5-\{[(4-amino-5-chloro-2-methylphenyl $)$ sulfonyl]amino $\}$ 1,3,4-thiadiazol-2-yl) sulfonyl]-4-chlorobenzamide (9f). Yield $53.29 \%$, m.p. $268^{\circ} \mathrm{C}, \mathrm{R}_{\mathrm{f}} 0.58, \log \mathrm{P} 4.052$. Found: $\mathrm{C} 39.80, \mathrm{H}$ 2.51, N 14.43, S $18.42 \%$. $\mathrm{C}_{16} \mathrm{H}_{13} \mathrm{~N}_{5} \mathrm{O}_{5} \mathrm{~S}_{3} \mathrm{Cl}_{2}$ (522.41) requires $\mathrm{C}$ 39.79, H 2.51, N 13.41, S 18.41\%. m/z (GC-MS): 516 (100\%, Base peak, $\left.\mathrm{M}^{+}\right)$. FT-IR $(\mathrm{KBr}) v_{\max } \mathrm{cm}^{-1}: 3407-3126(\mathrm{~N}-\mathrm{H}), 3107-3010(\mathrm{Ar}$ C-H), 1708-1685 (amide C=O), 692-621 (C-S), 1054-1081 (S=O), 1365, 1311, 1187 (sulphonamide), 3319 (sulphonamide N-H), 23602341 (heteroaromatic N-H), 1708 (heteroaromatic $\mathrm{C}=\mathrm{N}$ ), 972-846 (C-N), 2894 (C-H), 592-532 (C-Cl). $\lambda_{\text {max }}$ (chloroform) (lge)/nm 285. ${ }^{1} \mathrm{H}$ NMR (DMSO- $\left.d_{6}\right) \delta_{\mathrm{H}} \mathrm{ppm}: 2.071\left(\mathrm{~s}, 1 \mathrm{H}, \mathrm{Ar}-\mathrm{SO}_{2} \mathrm{NH}\right), 4.139$ (s, 3H, Ar- $\left.\mathrm{CH}_{3}\right), 4.652$ (s, 2H, Ar-NH $)$, 6. 539-7.214 (s, 2H, Arunsymmetrical pattern), 7.623-7.851 (m, 6H, Ar-H), 7.046-7.973 (s, $\left.2 \mathrm{H}, \mathrm{NH}_{2}\right), 8.534-8.743(\mathrm{~s}, 1 \mathrm{H}$, thiadiazole, $\mathrm{C}-\mathrm{H}) .{ }^{13} \mathrm{C}$ NMR $\delta_{\mathrm{c}} \mathrm{ppm}$ : $169.8,147.5,137.7,135.6,132.2,130.5,129.0,129.0,128.8,128.8$, $127.7,122.4,117.8,16.9$.

$N$-[(5-\{[(4-amino-5-methoxy-2-nitrophenyl) sulfonyl]amino $\}$ 1,3,4-thiadiazol-2-yl) sulfonyl]benzamide (9g). Yield $21.24 \%$, m.p. $252^{\circ} \mathrm{C}, \mathrm{R}_{\mathrm{f}}$ 0.47, $\log \mathrm{P} 4.006$. Found: $\mathrm{C} 37.37, \mathrm{H} 2.71, \mathrm{~N} 16.33$, $\mathrm{S} 18.72 \% . \mathrm{C}_{16} \mathrm{H}_{13} \mathrm{~N}_{6} \mathrm{O}_{8} \mathrm{~S}$ Cl (514.51) requires $\mathrm{C} 37.35, \mathrm{H} 2.74$, N 16.33, S $18.70 \%$. m/z (GC-MS): 523 (100\%, Base peak, $\left.\mathrm{M}^{+}\right)$. FT-IR (KBr) $v_{\max } \mathrm{cm}^{-1}$ : 3359-3338 (N-H), 3082-3045 (Ar C-H), 1691-1629 (amide $\mathrm{C}=\mathrm{O}$ ), 678-669 (C-S), 1035 ( $\mathrm{S}=\mathrm{O}), 1342$, 1319, 1157 (sulphonamide), 3338 (sulphonamide N-H), 23812341 (heteroaromatic N-H), 1515-1452 (Ar C-NO $), 1785-1735$ (heteroaromatic $\mathrm{C}=\mathrm{N}), 559(\mathrm{C}-\mathrm{Cl}), 960-827(\mathrm{C}-\mathrm{N}), 2943(\mathrm{C}-\mathrm{H})$. $\lambda_{\max }$ (chloroform) $(\lg \varepsilon) / \mathrm{nm} 288 .{ }^{1} \mathrm{H}$ NMR (DMSO- $\left.d_{6}\right) \delta_{\mathrm{H}} \mathrm{ppm}$ : $2.146\left(\mathrm{~s}, 1 \mathrm{H}, \mathrm{Ar}-\mathrm{SO}_{2} \mathrm{NH}\right), 3.927$ (s, 3H, Ar- $\left.\mathrm{OCH}_{3}\right), 4.201$ (s, $2 \mathrm{H}$, Ar- $\mathrm{NH}_{2}$ ), 6.539-7.412 (s, 2H, Ar-unsymmetrical pattern), 7.023$7.851(\mathrm{~m}, 5 \mathrm{H}, \mathrm{Ar}-\mathrm{H}), 6.957-7.077\left(\mathrm{~s}, 2 \mathrm{H}, \mathrm{NH}_{2}\right) .{ }^{13} \mathrm{C} \mathrm{NMR} \delta_{\mathrm{c}} \mathrm{ppm}$ :
$170.0,154.1,140.8,138.4,134.3,132.2,128.6,128.4,127.6,127.3$ 125.3, 115.6, 112.8, 56.1.

5-\{[(4-Aminophenyl) sulfonyl]amino $\}-1,3,4$-thiadiazole2-sulfonamide (10a). Yield $42.04 \%$, m.p. $194^{\circ} \mathrm{C}, \mathrm{R}_{\mathrm{f}} 0.60, \log \mathrm{P}$ 0.840. Found: C 28.67, H 2.71, N 20.89, S $28.68 \%$. $\mathrm{C}_{8} \mathrm{H}_{9} \mathrm{~N}_{5} \mathrm{O}_{4} \mathrm{~S}_{3}$ (335.38) requires C 28.65, H 2.70, N 20.88, S $28.68 \% . \mathrm{m} / z$ (GCMS): $319\left(100 \%\right.$, Base peak, $\left.\mathrm{M}^{+}\right)$. FT-IR $(\mathrm{KBr}) v_{\max } \mathrm{cm}^{-1}: 3398-$ 3378 (N-H), 3120-2793 (Ar C-H), 706 (C-S), 1080-1026 (S=O), 1358, 1293, 1080 (sulphonamide), 3320 (sulphonamide N-H), 2378-2351 (heteroaromatic N-H), 1686 (heteroaromatic $\mathrm{C}=\mathrm{N}$ ). $\lambda$ (chloroform) $(\lg \varepsilon) / \mathrm{nm} \mathrm{260.}{ }^{1} \mathrm{H}$ NMR (DMSO- $\left.d_{6}\right) \delta_{\mathrm{H}} \mathrm{ppm:} 1.254$ $\left(\mathrm{s}, 1 \mathrm{H}, \mathrm{Ar}-\mathrm{SO}_{2} \mathrm{NH}\right), 7.228-8.123(\mathrm{~m}, 6 \mathrm{H}, \mathrm{Ar}-\mathrm{H}), 8.611(\mathrm{~s}, 1 \mathrm{H}$, sulphonamido-H). ${ }^{13} \mathrm{C}$ NMR $\delta_{\mathrm{c}}$ ppm: 151.4, 129.9, 128.2, 128.1, 116.4, 116.3 .

5-\{[(4-Amino-5-methoxy-2-nitrophenyl)sulfonyl]amino $\}$ 1,3,4-thiadiazole-2-sulfonamide (10b). Yield $34.58 \%$, m.p. $222^{\circ} \mathrm{C}$, $\mathrm{R}_{\mathrm{f}} 0.65, \log \mathrm{P}-1.174$. Found: C 26.36, H 2.47, N 20.49, S $23.43 \%$. $\mathrm{C}_{9} \mathrm{H}_{10} \mathrm{~N}_{6} \mathrm{O}_{7} \mathrm{~S}_{3}$ (410.41) requires C 26.34, H 2.46, N 20.48, S $23.44 \%$. $\mathrm{m} / \mathrm{z}$ (GC-MS): $396\left(100 \%\right.$, Base peak, $\left.\mathrm{M}^{+}\right)$. FT-IR $(\mathrm{KBr}) \mathrm{v}_{\max } \mathrm{cm}^{-1}$ : 3358-3298 (N-H), 3127-2761 (Ar C-H), 726 (C-S), 1078-1014 $(\mathrm{S}=\mathrm{O}), 1532-1476($ Ar C-NO $), 1358,1293,1080$ (sulphonamide), 3320 (sulphonamide $\mathrm{N}-\mathrm{H}$ ), 2398-2371 (heteroaromatic N-H), 1677 (heteroaromatic $\mathrm{C}=\mathrm{N}), 569-527(\mathrm{C}-\mathrm{Cl}), 2873(\mathrm{C}-\mathrm{H}) . \lambda_{\max }$ (chloroform) (lge)/nm 278. ${ }^{1} \mathrm{H}$ NMR (DMSO- $\left.d_{6}\right) \delta_{\mathrm{H}} \mathrm{ppm}: 1.425(\mathrm{~s}$, $\left.1 \mathrm{H}, \mathrm{Ar}-\mathrm{SO}_{2} \mathrm{NH}\right), 3.108\left(\mathrm{~s}, 3 \mathrm{H}, \mathrm{OCH}_{3}\right), 3.527$ (s, $\left.2 \mathrm{H}, \mathrm{Ar}-\mathrm{NH}_{2}\right), 7.334-$ $8.312(\mathrm{~m}, 2 \mathrm{H}, \mathrm{Ar}-\mathrm{H}), 8.611$ (s, $1 \mathrm{H}$, sulphonamido-H). ${ }^{13} \mathrm{C}$ NMR $\delta_{\mathrm{c}}$ ppm: $153.1,140.2,138.7,125.3,115.2,112.9,56.1$.

\section{Pharmacology}

The anticonvulsant evaluations were undertaken using reported procedure. ${ }^{[28-30,33]}$ Male albino mice (CF-1 strain or swiss, 25-35 g) and rats (Sprague-Dawley or Wistar, 100-150 g) were used as experimental animals. The tested compounds were suspended in polyethylene glycol 400 .

Anticonvulsant screening. Initially all the compounds were administered orally in a volume of $100 \mathrm{mg} / \mathrm{kg}$ body weight of mice, $60 \mathrm{~min}$ prior to the electroshock. The electroshock induced in animal by passing a current of $45 \mathrm{~mA}$ for $0.2 \mathrm{sec}$ duration through electroconvulsiometer (Techno India) using corneal electrodes. The following phases in sequence and time in each phase (in seconds) was noted. ${ }^{[39-41]}$

\begin{tabular}{lll}
\hline 1. Tonic flexon & $: \begin{array}{l}\text { Contraction of muscle throughout the body } \\
\text { and forelimbs. }\end{array}$ \\
2. Tonic extension : & Extension of extremities. \\
3. Clonus & $:$ Stage of relaxation after extension. \\
4. Stupor & $: \begin{array}{l}\text { Stage of unconsciousness before recovery } \\
\text { (Generally more than one minute) }\end{array}$ \\
\hline
\end{tabular}

While in scPTZ test, all the drugs were administered orally 30 min prior to the administration of pentylenetetrazole $(6 \mathrm{mg} / \mathrm{kg})$ by subcutaneous injection. The animals were observed for 1 and 3 hour by placing in a separate cage. The duration of seizures (tonic-clonic convulsions) were recorded. ${ }^{[42]}$ Activity was established using the MES and scPTZ test and these data are presented in Table 5.

Diuretic activity. The Lipschitz method was employed for the assessment of diuretic activity. ${ }^{[43]}$ The rats were deprived of food for $18 \mathrm{~h}$ and tap water ad libitum was allowed. The urine was collected quantitatively for a total period of four hours and the urine collected of initially of $20 \mathrm{~min}$. was discarded. ${ }^{[44]}$ The effect of the compounds was compared with standard and the control group. The ratio (T/C, $\mathrm{T} / \mathrm{S}$ ) of urine volume of treated and control group was determined. ${ }^{[45-46]}$ The results are shown in Table 6.

Acknowledgements. The authors are highly thankful to Director, Sophisticated Analytical Instrument Facility 
(SAIF), Chandigarh, Pune University, Pune for providing the necessary spectral analysis, and Head, Department of Pharmacy, SGVU, Jaipur for providing necessary laboratory facilities to carry out this research work.

\section{References}

1. Malawska B. Curr. Top. Med. Chem. 2005, 5(1), 69-85.

2. Shindikar A.V., Khan F., Viswanathan C.L. Eur. J. Med. Chem. 2006, 41, 786-792.

3. Brunton L.L., Chabner B.A., Knollmann B.C. Pharmacotherapy of the Epilepsies. In: Goodman \& Gilman's The Pharmacological Basis of Therapeutics (James O.M., Ed.) 12 $2^{\text {th }}$ Edn., New Delhi: McGraw-Hill, 2010.

4. Supran C.T., Scozzafava A., Casini A. Med. Res. Rev. 2003, 23(2), 146-189.

5. Supran C.T., Masereel B., Rolin S., Scozzafava A. J. Med. Chem. 2002, 45, 312-320.

6. Supran C.T., Scozzafava A., Daniela V., Montero J.L., Gangard V., Innocenti A., Winum J.Y. Bioorg. Med. Chem. Lett. 2005, $15(6), 1653$

7. Christianson D.W. Rigaku J. 1996, 13(1), 8-15.

8. Robin R.O. Jr., Clapp J.W. J. Am. Chem. Soc. 1950, 72, 4890.

9. Robin R.O. Jr., Miller W.H., Dessert A.M. J. Am. Chem. Soc. 1950, 72, 4893

10. Mullican M.D., Wilson M.W., Connor D.T., Kostlan C.R., Schrier D.J., Dyer R.D. J. Med. Chem. 1993, 36(8), 10901099.

11. Onkol T., Cakir B., Sahin M.F., Yildirim E., Erol K. Turk. J. Chem. 2004, 28, 461-468.

12. Dutta M.M., Goswami B.N., Kotaky J.C.S. J. Heterocycl. Chem. 1986, 23(3), 793-795.

13. Oruc E.E., Rollas S., Kandemirli F., Shvets N., Dimoglo S. J. Med. Chem. 2004, 47(27), 6760-6767.

14. Shukla S.K., Singh S.P., Nautiyal S.R., Mukherjee D.D. Indian Drugs 1982, 20, 21.

15. Saksena R.K., Puri S., Prakash R. J. Heterocycl. Chem. 2003, 13(2), 127-130

16. Hanna M.A., Girges M.M., Rasala D., Gawinecki R. ArzeneimForsch Drug Res. 1995, 45(10), 1074-1078.

17. Cross P.E., Dickinson P.R. Chem. Abstr. 1978, 88, 190839t.

18. Zuhair M.E., Fuad A.J., Shamis E., Sabah A.K., Hanan G., Murfied G. Chem. Abstr. 1983, 98, 72006c.

19. Nizamuddin, Singh A. Indian J. Chem. 2004, 43B, 901-905.

20. Ward J.S. Chem. Abstr. 1977, 87, 201546c.

21. Zhang Y.X., Xua W.T. Chem. Abstr. 1996, 124(23), 317071 f.

22. Taranalli A.D., Ahmed A., Patil B.M. Indian Drugs 1995, 29(14), 643-648.

23. Stillings M.R., Welbourn A.P., Walter D.S. J. Med. Chem. 1986, 29(11), 2280-2284.
24. Supran C.T., Scozzafava A., Owa T., Casini A., Abbate F. Bioorg. Med. Chem. Lett. 2004, 14, 217-223.

25. Supran C.T., Scozzafava A., Casini A., Abbate F. Bioorg. Med. Chem. Lett. 2003, 13, 2759-2763.

26. Supran C.T., Scozzafava A., Antel J., Gallori E., Franchi M., Vullo D. J. Med. Chem. 2004, 47, 1272-1279.

27. Vogel's Textbook of Practical Organic Chemistry, (Furniss B.S., Hannaford A.J., Smith P.W.G., Tatchell A.R., Eds.) $5^{\text {th }}$ Edn., London: ELBS Publications, 1996. p. 1273.

28. Martin Y.C. Theoretical Basis of Medicinal Chemistry: Structure Activity Relationship and Three Dimensional Structures of Small and Macromolecules. In: Modern Drug Research, Path to Better and Safer Drugs (Martin Y.C., Austel V., Kutter E. Eds.) New York: Marcel Dekker, 1989, p. 161.

29. McForland J.W., Gans D.J. Comprehensive Medicinal Chemistry 3. Oxford: Pergamon Press, 1990. p. 667.

30. Kubinyi H. QSAR: Hansch Analysis and Related Approaches, New Delhi: VCH Publishers, 1993. p. 91.

31. Dimmock J.R., Pandeya S.N., Quail J.W., Pugazhenthi U., Allen T.M., Kao G.Y., Balzarini J., Clercq E.D. Eur. J. Med. Chem. 1995, 30, 303-314.

32. Dimmock J.R., Sidhu K.K., Tumber S.D., Basran S.K., Chen M., Quail J.W., Yang J., Rozas I., Weaver D.F. Eur. J. Med. Chem. 1995, 30, 287-301.

33. Burgers Medicinal Chemistry and Drug Discovery Principle and Practice, Vol.1, (Kubinyi H., Wolff M.E. Eds.) $5^{\text {th }}$ Edn. New York: Wiley Interscience Publication, 1995. p. 505.

34. CS Chem Office, Version 6.0, Cambridge Soft Corporation, Software Publisher Association, 1730 M Street, NW, Suite 700, Washington DC, 20036 (202), 452-1600, USA.

35. SYSTAT 10.2 version supplied by SYSTAT SOFTWARE INC.

36. Gupta A.K., Babu M.A., Kaskhedikar S.G. Ind. J. Pharm. Sci. 2004, 66, 396-402.

37. Perun T.J., Propst C.L. Computer Aided Drug Design Methos and Applications. Marcel Decker Inc: New York, 1989, p. 2.

38. Gerhard K., Abrahum U.J. Computer Aided Molecular Designs 1999, 22, 473

39. Rajasekaran A., Murugesan S., Ananda Rajagopal K. Arch Pharm. Res. 2006, 29, 535-540.

40. Balakrishnan S., Pandhi P., Bhargava V.K. Ind. J. Exp. Biol. 1998, 36, 51-54.

41. Principles of Medicinal Chemistry (Foye W.O., Ed.), $3^{\text {rd }}$ Edn. Bombay: Verghese Publishing House, 1989. p. 173.

42. Khosla P., Pandhi P. Ind. J. Pharmacol. 2001, 33, 208-211.

43. Lipschitz W.L., Hadian, Kerpscas A. J. Pharmcol. Exp. Ther. 1943, 79, 97-110.

44. Grover J.K. Anticonvulsant. In: Experiments in Pharmacy and Pharmacology, Vol II. New Delhi: CBS Publishers and Distributors, 1990. p. 162.

45. Jain S.K., Mishra P. Ind. J. Chem. 2004, 43B, 184-188.

46. Jain S.K., Mishra P., Chem. Abstr. 2004, 140, 287334 e. 